\title{
Cheap Food and Bad Climate: From Surplus Value to Negative Value in the Capitalist World-Ecology
}

Jason W. Moore, Binghamton University

\begin{abstract}
Capitalism, understood as a world-ecology that joins accumulation, power, and nature in dialectical unity, has been adept at evading so-called Malthusian dynamics through an astonishing historical capacity to produce, locate, and occupy cheap natures external to the system. In recent decades, the last frontiers have closed, and this astonishing historical capacity has withered. This "withering" is perhaps most evident in capitalism's failure to offer a new, actually productive, agricultural model-as agrobiotechnology failed to deliver on its promissory notes. Moving from bad to worse, a second set of contradictions is now mediated through climate change. Climate change, one among many ongoing biospheric shifts, is interwoven with the totality of neoliberal agriculture's contradictions to produce a new contradiction: negative value. This signals the emergence of forms of nature that are increasingly hostile to capital accumulation and that can be temporarily fixed (if at all) only through increasingly costly, toxic, and dangerous strategies. The rise of negative value-whose accumulation has been latent for much of capitalist history-therefore suggests a significant and rapid erosion of opportunities for the appropriation of new streams of unpaid work/energy. As such, these new limits are qualitatively different from the nutrient and resource depletion of earlier, developmental crises of the longue durée Cheap Food model. These contradictions, within capital, arising from negative value, are today encouraging an unprecedented shift toward a radical ontological politics, within
\end{abstract}

Special thanks to William H. Sewell Jr. and four anonymous reviewers, and to Diana C. Gildea, Christian Parenti, Richard Walker, Harriet Friedmann, Henry Bernstein, Haroon Akram-Lodhi, Phil McMichael, Joshua Eichen, Ben Marley, Jay Bolthouse, Vishrut Arya, Manuel Francisco Varo, Alvin Camba, Roberto J. Ortiz, and Christopher Cox for conversations and correspondence on this article and its themes.

Critical Historical Studies (Spring 2015). ( 2015 by The University of Chicago. All rights reserved. 2326-4462/2015/0201-0001\$10.00 
capitalism as a whole, that destabilizes crucial points of agreement in the modern world system: What is food? What is nature? What is valuable?

n 2001, food was cheaper than at any time in modern world history. ${ }^{1}$ This began to change in 2002, as food prices ticked upward. Slowly at first. Then rapidly. Prices peaked in 2008, and again in the early months of 2011 . According to the Food and Agricultural Organization of the United Nations, food prices are higher today than in 2008. In short, the food "crisis" never went away. Food commodity prices in 2014 were 127 percent higher than in $2002 .^{2}$ There is no end in sight. Capitalism has swept cheap food-one of its central organizing principles-into the dustbin of history.

It wasn't supposed to happen this way. Capitalism's greatest achievement has been the unprecedented development of agricultural productivity. Modernity is unthinkable without it. For five centuries before 2002, food became cheaper and cheaper for the world's working classes, which grew larger and larger over time. There had always been a few moments of price inflation. But these were, time and again, fixed by new combinations of productivity and plunder: new agronomies, new machines, new farm organization, and, most of all, new frontiers. This is the story of agricultural revolutions in the modern world.

For the past decade, journalist and scholars_often implicitly-have questioned this agricultural revolution model. Nearly all have focused on particular thematic and regional dimensions of capitalist agriculture's systemic contradictions: cash cropping and deforestation, neoliberal restructuring and food insecurity, dispossession, biotechnology, agrofuels, and all the rest. ${ }^{3}$ This article attempts to do something different. My question is this: on its own terms, can capitalism in the twenty-first century successfully reproduce its longue durée agricultural model?

1. G. Buntrock, "Cheap No More," The Economist, December 6, 2007.

2. Calculated from the average of the first 11 months of 2014, from Food and Agricultural Organization of the United Nations, "World Food Situation: FAO Food Price Index," n.d., accessed January 14, 2015, http://www.fao.org/worldfoodsituation/foodpricesindex/en/.

3. The literature is impossibly vast. A representative sampling would include Michael Pollan, The Omnivore's Dilemma: A Natural History of Four Meals (New York: Penguin, 2006); Raj Patel, Stuffed and Starved (New York: Melville House, 2007); Richard Manning, Food's Frontier: The Next Green Revolution (Berkeley: University of California Press, 2000); Tony Weis, The Global Food Economy (London: Zed, 2007); Philip McMichael, Food Regimes and Agrarian Questions (Halifax: Fernwood, 2013); Harriet Friedmann, "Feeding the Empire," in The Empire Reloaded: Socialist Register 2005, ed. Leo Panitch and Colin Leys (London: Merlin, 2005), 124-43; Frederick Kaufman, Bet the Farm: How Food Stopped Being Food (Hoboken, NJ: Wiley, 2012); Jan Douwe van der Ploeg, The New Peasantries: Struggles for Autonomy and Sustainability in an Era of Empire and Globalization (London: Earthscan, 2008); François Houtart Agrofuels: Big Profits, Ruined Lives and Ecological Destruction (London: Pluto Press, 2010). 
Are we seeing-or are we likely to see-a new agricultural revolution that produces more commodity food with less labor power, sufficient to feed, cheaply, an expanded world proletariat? Will there be a "new" green-or biotech-revolution? And will it restore cheap food?

I want to answer these questions by weaving together an account of two entwined, but distinct, contradictions within the longue durée cheap food regime. The first set of contradictions turns on the cumulative evolution and cyclical development of the capitalist agricultural model. ${ }^{4}$ I will strip down this model to just two basic moments. The first is the imperative to advance labor productivity, so as to kill two birds with one stone: enlarge the reserve army of labor and reduce the reproduction costs of labor power. The working population outside agriculture may grow and be fed more cheaply than before. ${ }^{5}$ The analytical problem arises when we understand that capitalism pursues more than one strategy for producing Cheap Food: "cheap" in the sense of reducing the value composition of food below the systemwide average for all commodities. Advancing labor productivity is necessary but insufficient to realize such cheap food. ${ }^{6}$ The "fundamental limiting factor" of capitalist development is not labor or land productivity as such, but the repertoire of strategies that enlarge the "marketable surplus." 7 Agricultural output with low labor productivity-taken in a narrow sense-has often been indispensable to cheap food revolutions. Polish serfs or African slaves channeled rivers of rye, wheat, and sugar into the heartlands of early capitalism. ${ }^{8}$ Today, small cultivators across the Global South today feed much of the world, but on small-and shrinking_-plots, even as their labor productivity pales in comparison

4. This is a hegemonic and not a general model. There is no attempt here to suggest that all agriculture-even and especially within the orbit of capital relations-assumed the same organizational form or class structure; only that there have been successive agricultural revolutions through which new configurations of state and capital, world market and geopolitics, class and cultivation become pivotal to the renewal of capital accumulation by providing ever-greater volumes of cheap food to an ever-greater world proletariat.

5. Jason W. Moore, "The End of the Road? Agricultural Revolutions in the Capitalist WorldEcology, 1450-2010," Journal of Agrarian Change 10, no. 3 (2010): 389-413.

6. Henry Bernstein's Class Dynamics of Agrarian Change (Halifax, NS: Fernwood, 2010) offers one useful introduction to the thorny questions of agricultural productivity.

7. Maurice H. Dobb, Some Aspects of Economic Development (Delhi: Delhi School of Economics, 1951), 45 .

8. Jason W. Moore, "Ecology and the Rise of Capitalism" (PhD diss., University of California, Berkeley, 2007), “Amsterdam Is Standing on Norway' Part I: The Alchemy of Capital, Empire, and Nature in the Diaspora of Silver, 1545-1648," Journal of Agrarian Change 10, no. 1 (2010): 35-71, "Amsterdam Is Standing on Norway' Part II: The Global North Atlantic in the Ecological Revolution of the Long Seventeenth Century," Journal of Agrarian Change 10, no. 2 (2010): 188-227. 
to the North. ${ }^{9}$ To the degree that the reproduction costs of these small cultivators can be suppressed, or fobbed off on noncommodity relations, low-productivity farming can-and has been-central to cheap food.

The political economy of cheap food-turning on the food/labor power nexusis one part of the model. The other is the political ecology of cheap food. From its sixteenth-century origins, cash-crop agriculture has exhausted land and laborboth substantially (soils mined, bodies destroyed) and relationally (particular class structures, agronomic techniques, etc.). The sugar commodity frontier is a paradigm instance, not simply mining soils but restructuring production at each step in its long march across the early modern Atlantic. ${ }^{10}$ English agriculture may seem a more benign example-and is clearly distinctive, as we shall see-but its cash-crop model exhausted itself by the middle of the eighteenth century. The crucial contradiction may be stated clearly enough: capitalist agriculture "works" by appropriating agroecosystems as a force of production; the drive to advance labor productivity compels a temporality at odds with healthy agrosystemic reproduction; over time, in the absence of off-farm inputs, labor productivity growth slows.

The two moments-political economy and political ecology-may now be combined in a historical sketch. The emergence of the agroindustrial model in North America after 1840 was a decisive turning point in this long-run model. The "first" agroindustrial model, exhausted by the early decades of the twentieth century, in the 1930s yielded to a second, the "long Green Revolution." ${ }^{11}$ This model, too, would show signs of exhaustion by the turn of the 1990s. Every agricultural revolution is self-limiting, not because of Malthusian food/people growth curves but because capitalist temporality systematically encourages the exhaustion of agroecosystems, $^{12}$ undermining their capacities to yield more and more unpaid

9. Food and Agricultural Organization of the United Nations, State of Food and Agriculture: Innovation in Family Farming (Rome: Food and Agriculture Organization, 2014), chap. 3 and esp. 33; GRAIN, Hungry for Land, GRAIN report, 2014, accessed June 24, 2014, http://www.grain.org/article/entries 14929-hungry-for-land-small-farmers-feed-the-world-with-less-than-a-quarter-of-all-farmland; Weis, Global Food Economy.

10. Moore, "Ecology"; Jason W. Moore, "Madeira, Sugar, and the Conquest of Nature in the 'First' Sixteenth Century, Part I," Review 32, no. 4 (2009): 345-90, and "Madeira, Sugar, and the Conquest of Nature in the 'First' Sixteenth Century, Part II," Review 33, no. 1 (2010): 1-24.

11. Raj Patel, "The Long Green Revolution," Journal of Peasant Studies 40, no. 1 (2013): 1-63.

12. There is of course more than one capitalist temporality. Time, as with space, is multilayered. In the capitalist era, however, the law of value (understood through the formation of socially necessary labor time) exerts a determining influence. The classic account of time and capital, beyond Marx's work, is Moishe Postone, Time, Labor, and Social Domination (Cambridge: Cambridge University Press, 
work/energy into the circuit of capital. ${ }^{13}$ Capitalism has proven to be adept at evading (so-called) "natural limits" through its astonishing historical capacity to produce, locate, and occupy cheap natures external to the system. ${ }^{14}$ In recent decades, the frontiers have closed, and this astonishing historical capacity has withered. As these frontiers have contracted, a new emphasis on redistribution appeared. In the North, wage repression became the new normal. ${ }^{15}$ In the South, "forced underconsumption" suppressed the food consumption of billions. ${ }^{16}$ This withering of capitalism's productive dynamism is perhaps most evident in the pronounced failure of agrobiotechnology to restore cheap food. The situation that has emerged-even if all else were equal-is therefore quite distinctive. We now live in a world system where the rate of proletarianization exceeds the rate of agricultural productivity growth. Thus the centrality of cheap food-and its erosion-in the present conjuncture.

Moving from bad to worse, a second set of contradictions is now taking shape. These contradictions pivot on climate change but are not reducible to it. Rather than catalog the impacts of climate change alongside those of longer-run contradictions, my intention is to show how climate change entwines with the totality of neoliberal agriculture's contradictions to produce a new set of challenges: negative value. In this reading, climate (and the rest of nature) does not exist as an external barrier but rather is coconstitutive of a new set of contradictions. Negative value refers to the ferocious combination of rising costs of production (an old cumulative dynamic) with the novel global conjoncture of planetary instability and unpredictability expressed by climate change. The paired, but spatially and temporally uneven, processes of extracting nature's "free gifts" (including human work) and toxifying the biosphere (including humans) have now reached a breaking point. The accumulation of negative value, immanent but latent from the origins of capitalism, is now issuing a layer of contradictions that can no longer

1993); see also William H. Sewell Jr., “Temporalities of Capitalism," Socio-Economic Review 6 (2008): 517-37.

13. The phrase "work/energy" originates with Caffentzis in a groundbreaking 1980 essay on the interconnected crises of energy, labor power, and social reproduction in the 1970s. See George Caffentzis, "The Work/Energy Crisis and the Apocalypse," in Letters of Blood and Fire: Work, Machines, and the Crisis of Capitalism (Oakland, CA: PM Press, 2013), 11-57.

14. Jason W. Moore, "The End of Cheap Nature or: How I Learned to Stop Worrying about 'the' Environment and Love the Crisis of Capitalism," in Structures of the World Political Economy and the Future of Global Conflict and Cooperation, ed. Christian Suter and Christopher Chase-Dunn (Berlin: LIT, 2014), 285-314.

15. David Harvey, A Brief History of Neoliberalism (Oxford: Oxford University Press, 2005).

16. Farshad Araghi, "Accumulation by Displacement: Global Enclosures, Food Crisis, and the Ecological Contradictions of Capitalism," Review 32, no. 1 (2009): 113-46. 
be "fixed" by technical, organizational, or imperial restructuring. Put simply, the ongoing closure of frontiers limits the capacity of capital and states to accomplish two necessary goals: (1) attenuate the rising costs of production; and (2) remove the geometrically rising volume of waste from the global determination of profitability. If capitalism is an "economy of unpaid costs," ${ }^{17}$ the bills are coming due. And if only that were the crux of the problem! For capitalism is also a system of unpaid work.

But how do we conceptualize relation of paid and unpaid work? In what follows, I understand capital accumulation to work through two entwined but distinct movements: accumulation by capitalization and accumulation by appropriation. I take paid work (capitalization) to be the domain of the capital-labor conflict over shares of value. This is the question of exploitation. I take unpaid work to be a struggle over the forms and relations of capital to unmonetized social reproduction (e.g., "domestic labor) and to the "work of nature." ${ }^{18}$ This is the question of appropriation. In this, wage work emerges as the zone of exploitation: accumulation by capitalization. But capitalization depends on an even greater movement: the appropriation of the unpaid work of human and extrahuman natures. This is accumulation by appropriation.

My use of "appropriation" therefore differs from that of Marx, who deployed the term more or less interchangeably with the exploitation of wage labor. Accumulation by appropriation names those extraeconomic processes that identify, secure, and channel unpaid work outside the commodity system into the circuit of capital. Scientific, cartographic, and botanical revolutions, broadly conceived, are good examples. Movements of appropriation, in this sense, are distinct from movements of the exploitation of wage labor. So important is the appropriation of unpaid work that the rising rate of exploitation depends upon the fruits of appropriation derived from Cheap Natures, understood primarily as the "Four Cheaps": labor power, food, energy, and raw materials.

17. K. William Kapp, The Social Costs Of Private Enterprise (New York: Schocken, 1950), 231.

18. This relation between capital and the mobilization of unpaid work is, of course, mediated by the state. I have imprudently, but necessarily, abstracted this moment from present argument. The elements of a socioecological synthesis of state, capital, and unpaid work can be found in James O'Connor, Natural Causes: Essays in Ecological Socialism (New York: Guilford, 1998); and James C. Scott, Seeing Like a State (New Haven, CT: Yale University Press, 1998). Christian Parenti's groundbreaking work on the "environment making state" may be read as a companion to the present argument; see "The Environment Making State: Territory, Nature, and Value," Antipode, published electronically 2014, doi: 10.1111 /anti.12134. 
Today, this relation—of capitalization and appropriation-faces new challenges. It is not simply that there are no more great frontiers. There are indeed fewer opportunities to appropriate the free gifts of human and extrahuman nature. But there is a new contradiction in play: the rise of negative value. The present conjuncture combines depletion, class struggle, and the unprecedented biospheric unpredictability issuing from capital's transgression of "planetary boundaries." ${ }^{19}$ It is a potent cocktail. Together, they shape a dynamic of an impending and catastrophic shift for capital: a radical increase in the costs of production. This is the hallmark of an ongoing transition from "surplus" to "negative" value. The signs of this transition are, as I will show, all around us. My thesis is simple: the core processes of capital accumulation are now generating increasingly direct and immediate barriers to the expanded reproduction of capital. These contradictions within capital, arising from negative value, are today encouraging an unprecedented shift toward movements against capital. These are crystallized around a new radical "ontological" challenge-food sovereignty above all—that destabilizes crucial points of agreement in the modern world system: What is food? What is nature? What is valuable?

\section{CHEAP FOOD IN THE CAPITALIST WORLD-ECOLOGY}

Cheap food is "cheap" in a specific sense: more calories produced with less average labor time in the commodity system. In this context, "more calories" and "less labor time" refer to the long-run trend: more and more calories, less and less socially necessary labor time. Capitalist agriculture not only increased productivity and reduced the wage bill; it also made possible the dynamic pairing of proletarianization and rising labor productivity: not only by setting "free" peasants and others once tied to the land, but also by reducing the cost (value composition) of labor power, which facilitates a rising rate of exploitation even in the absence of significant technical advance.

There have certainly been noncapitalist modes of cultivation that have enjoyed very high levels of food production with very modest effort. Where an average "worker-hour" in English agriculture around 1800 yielded about 2,600 calories, premised on milk and wheat, the average "worker-hour" in swidden agriculture in early nineteenth-century Brazil, cultivating manioc, maize, and sweet potatoes, yielded between 7,000 and 17,600 calories. $^{20}$ But nowhere was rising labor pro-

19. Johan Rockström et al., "Planetary Boundaries: Exploring the Safe Operating Space for Humanity," Ecology and Society 14, no. 2 (2009), http://www.ecologyandsociety.org/vol14/iss2/art32/.

20. Gregory Clark, Farewell to Alms (Princeton, NJ: Princeton University Press, 2007), 67-68. 
ductivity in agriculture realized over such a longue durée, and over such vast geographies, until the rise of capitalism. ${ }^{21}$

The Cheap Food model worked something like this. Capitalism's agricultural revolutions worked by providing cheap food, which reduces the minimum wage threshold for workers, to an expanding proletariat. This reduced capital's wage bill even as the scale of proletarianization increased, allowing the rate of exploitation to rise, and with it, the mass of accumulated capital. ${ }^{22}$ But the mass of accumulated capital could only continue to grow insofar as a rising food surplus underwrote "cheap" proletarianization. It is a simple model. But I think it can tell us something important about the present conjuncture. For cheap food is so fundamental to the reproduction of labor power that its ongoing demise represents a fundamental break with five centuries of capitalist history.

I understand these five centuries of capitalist history in two registers: First, I see capitalism as not an economic system but as a "world-ecology" in which the

21. Moore, "Ecology"; Robert Brenner, "Agrarian Class Structure and Economic Development in Pre-Industrial Europe," Past \& Present 70 (1976): 30-75, and "The Low Countries in the Transition to Capitalism," Journal of Agrarian Change 1, no. 2 (2001): 169-241.

22. Moore, "End of the Road?," and "Cheap Food \& Bad Money: Food, Frontiers, and Financialization in the Rise and Demise of Neoliberalism," Review 33, nos. 2-3 (2012): 125-61. This model assumes that proletarianization unfolds via semiproletarianization; see Immanuel Wallerstein, Historical Capitalism (London: Verso, 1983); and Nancy Fraser, "Behind Marx's Hidden Abode," New Left Review II/86 (2014): 55-72. Efforts to expand the reserve of army of labor may indeed suppress wages for the working class, but a critical margin of survival is provided by a double relation to food: the cheapening of food's value composition through productivity advance (cheap food), and access to food by nonmarket means. Even in the United States, working-class families through the first half of the twentieth century often cultivated small vegetable gardens. About half of all such families in a midsized industrial town such as Muncie, Indiana, did so in the 1920s; during the 1930s, the working-class Los Angeles suburb of South Gate turned toward community gardening as key to surviving the Depression. See, respectively, Linda Gordon, "US Women's History," in The New American History, ed. Eric Foner (Philadelphia: Temple University Press, 1990), 271; and Becky M. Nicolaides, My Blue Heaven: Life and Politics in the Working-Class Suburbs of Los Angeles, 1920-1965 (Chicago: University of Chicago Press, 2002), 171-72. Although such moves toward decommodification have been occurring in recent years, a crucial difference in Global North today is the erosion consequent of practical knowledge, in relation not only to cultivation but also to food preparation (Paul Robert Gilbert, "Deskilling, Agrodiversity, and the Seed Trade," Agriculture and Human Values 30, no. 1 [2013]: 101-14; Clare Pettinger, Michelle Holdsworth, and Mariette Gerber, "Meal Patterns and Cooking Practices in Southern France and Central England," Public Health Nutrition 9, no. 8 [2006]: 1020-26; Phil Lyon, Anne Colquhoun, and Emily Alexander, "Deskilling the Domestic Kitchen: National Tragedy or the Making of a Modern Myth?," Food Service Technology 3, no. 3-4 [2003]: 167-75). These are important strategies for surviving an era of wage repression and rising food costs. Perhaps most significantly, the contraction of nonmarkets means of food acquisition makes even small shifts in food price index profound for households on the edge of food in/security. This makes high food prices in 2014 significantly different from the era of high food commodity prices in the period before World War I. 
endless accumulation of capital, the pursuit of power, and the coproduction of nature form an organic whole. ${ }^{23}$ In this analysis-our second register-capitalism becomes a set of relations through which work/energy is transformed into value, understood as socially necessary labor time (abstract social labor). "Work/energy" (or potential work/energy) may be capitalized-as in commodified labor power via the cash nexus-or it may be appropriated via noneconomic means, as in work of a river, waterfall, forest, or social reproduction. ${ }^{24}$ I take as a point of departure White's apt conceptualization of

energy as the capacity to do work. Work, in turn, is the product of a force acting on a body and the distance the body is moved in the direction of that force. Push a large rock and you are expending energy and doing work; the amount of each depends on how large the rock and how far you push it. The weight and flow of water produce the energy that allows rivers to do the work of moving rock and soil: the greater the volume of water in the river and the steeper the gradient of its bed, the greater its potential energy. ${ }^{25}$

White's sketch is focused on the geophysical work/energy implied in the historical geography of a river (the Columbia, in this instance). But work/energy is also about organic life: from photosynthesis to hunting prey to bearing children. What bears emphasis is how the work/energy of the web of life is incorporated into capitalism; how some becomes abstract social labor, and how most does not. This allows us to interpenetrate nature in its historical movements with human-initiated relations of wealth, life, and power. Food-in capitalism as for all civilizations-is a

23. Jason W. Moore, Capitalism in the Web of Life: Ecology and the Accumulation of Capital (London: Verso, 2015), "Transcending the Metabolic Rift," Journal of Peasant Studies 38, no. 1 (2011): 1-46, "End of the Road?," "Cheap Food," and "Cheap Nature"; Sharae Deckard, "Mapping the World-Ecology," Ecologies Technics $\theta$ Civilizations (forthcoming); Michael Niblett, "World-Economy, World-Ecology, World Literature," Green Letters 16, no. 1 (2012): 15-30; Christopher R. Cox, "Synthesizing the Vertical and the Horizontal: A World-Ecological Analysis of 'the' Industrial Revolution" (M.Sc. thesis, Portland State University, 2014); Aaron G. Jakes, "State of the Field: Agrarian Transformation, Colonial Rule, and the Politics of Material Wealth in Egypt, 1882-1914" (PhD diss., New York University, 2015); Benjamin Marley, "The Coal Crisis in Appalachia: Agrarian Transformation, Commodity Frontiers, and the Geographies of Capital," Journal of Agrarian Change, forthcoming, doi: 10.1111/joac.12104. Roberto José Ortiz, "Latin American Agro-industrialization, Petrodollar Recycling, and the Transformation of World Capitalism in the Long 1970s," Critical Sociology, published electronically 2014, doi: 10.1177/0896920514540187. Parenti, "Environment Making State"; Tony Weis, The Ecological Hoofprint: The Global Burden of Industrial Livestock (London: Zed, 2013).

24. The distinction between the exploitation (of labor power) and the appropriation of unpaid work performed by human and extrahuman natures is elaborated in Moore, Web of Life.

25. Richard White, The Organic Machine (New York: Hill \& Wang, 1995), 6. 
crucial nexus of all these: humans and the rest of nature coproducing wealth, life, and power.

\section{FROM AGRARIAN CAPITALISM TO THE LONG}

\section{GREEN REVOLUTION}

Cheap food was, of course, always cheap food for some. From the beginning, there were many people excluded from capitalism's cheap food regime; indeed, the majority of people in capitalist civilization have always been excluded from access to cheap food. The commodification of labor power always turns on the appropriation of unpaid work/energy from nature, including human work. ${ }^{26}$ The peripheries, not surprisingly, suffered most. Imperialist advance brought famine and food insecurity in its wake, from the conquest of the Americas to the incorporation of South Asia in the nineteenth century. ${ }^{27}$ The world proletariat, concentrated in the North Atlantic core, did not experience famine; subsistence crises were largely banished from Europe after the seventeenth century. ${ }^{28}$ When famines struck, they struck weakly proletarianized areas: Spain in the seventeenth century, not England and the Dutch Republic; Ireland and India in the nineteenth century, not America.

Nevertheless, the very dynamism of capital accumulation, agroecological transformation, and proletarianization could — and did-lead to serious food price inflation. Such moments have not occurred frequently, for reasons that have to do with capitalism's capacity to appropriate new frontiers of unpaid work/energy outside itself. The developmental crisis of the capitalist world-ecology in the late eighteenth century was one such moment. But since we are emphatically not dealing with a Malthusian system in which agricultural productivity translates directly to food access, biophysical productivity is only one indicator.

The 1760s marked the end of the "first" agricultural revolution that had made English industrialization possible ${ }^{29}$-largely by flooding the cities with cheap food

26. Moore, "Cheap Nature," and "The Capitalocene, Part II: Abstract Social Nature and the Limits to Capital," Journal of Peasant Studies (forthcoming).

27. Moore, "Ecology"; Mike Davis, Late Victorian Holocausts: El Niño Famines and the Making of the Third World (London: Verso, 2001).

28. Eric Vanhaute, "From Famine to Food Crisis: What History Can Teach Us about Local and Global Subsistence Crises," Journal of Peasant Studies 38, no. 1 (2011): 47-65; Andrew B. Appleby "Epidemics and Famine in the Little Ice Age, 1550-1700," Journal of Interdisciplinary History 10, no. 4 (1980): 643-63.

29. Brenner, "Agrarian Class Structure"; Robert C. Allen, "Tracking the Agricultural Revolution in England," Economic History Review 52, no. 2 (1999): 209-35. 
and cheap labor power. Just 39 percent of the English workforce was in agriculture by $1700 .{ }^{30}$ The half century after 1750 was marked by the failure of English agriculture to sustain its surging productivity of the previous century. ${ }^{31}$ As early as the 1740s, English agriculture "did not increase supplies of food and raw materials to match the rapidly growing demands of the urban industrial economy." ${ }^{32}$ Agricultural productivity growth slowed dramatically after 1760, and food prices began to increase. ${ }^{33}$ Even with sharply rising imports from Ireland, ${ }^{34}$ English food prices increased twice as fast as the industrial price index at the end of the eighteenth century. ${ }^{35}$ Relative to textiles and coal, food prices increased by 66 and 48 percent, respectively, between 1770 and $1795 .^{36}$

Nor was this a narrowly English phenomenon. Productivity faltered, inequality widened, and food prices increased throughout the Atlantic world. Output per worker was either falling or stagnant across western Europe in the half century after $1750 .{ }^{37}$ In France, food prices, mainly bread, shot up 65 percent-three

30. Stephen Broadberry, Bruce Campbell, and Bas van Leeuwen, "When Did Britain Industrialise?," Explorations in Economic History 50, no. 1 (2013): 23.

31. Agricultural labor productivity fell from .57 percent annually in 1700-59 to .41 percent between 1759 and 1801 (calculated from Broadberry, Campbell, and van Leeuwen, "When Did Britain Industrialise?," 23). For wheat, yield growth per acre averaged .38 percent annually over the period 1500-1700- 32 percent for the first half of the eighteenth century-but only .17 percent in 17591801. For rye-the poor man's cereal-yields actually fell, .13 percent annually in 1759-1801, after rising .47 percent annually for the two centuries after 1550 (calculated from Stephen Broadberry, Bruce Campbell, Alexander Klein, Mark Overton, and Bas van Leeuwen "British Economic Growth, 1270-1870" [unpublished manuscript, Department of Economic History, London School of Economics, 2011], 37, accessed August 8, 2014, http://www.unileipzig.de/ eniugh/congress/fileadmin/eniugh2011 /dokumente/ComparingLivingStandards_BroadberryCampbellKleinOvertonvanLeeuwen_2011_04_16 .pdf). Allen thinks output per worker in English agriculture declined in the second half of the eighteenth century; see Robert C. Allen "Economic Structure and Agricultural Productivity in Europe, 1300-1800," European Review of Economic History 3, no. 1 (2000): 20.

32. Patrick K. O'Brien "Agriculture and the Industrial Revolution," Economic History Review 30, no. 1 (1977): 175.

33. For Turner, English agricultural productivity slows from 1760; for Clark, from the 1770s; while Campbell and Overton see robust growth until 1800. See, respectively, Michael Turner, "Agricultural Productivity in Eighteenth-Century England," Economic History Review, 37, no. 2 (1984): 252-57; Gregory Clark, "Yields per Acre in English Agriculture, 1250-1860," Economic History Review 44, no. 3 (1991): 445-60; Bruce M. S. Campbell and Mark Overton, “A New Perspective on Medieval and Early Modern Agriculture: Six Centuries of Norfolk Farming c. 1250-c. 1850," Past \& Present 141 (1993): 38-105.

34. Brinley Thomas, "Feeding England during the Industrial Revolution," Agricultural History 56, no. 1 (1982): 328-42.

35. Patrick K. O'Brien "Agriculture and the Home Market for English Industry, 1660-1820," English History Review 100 (1985): 776.

36. Gregory Clark, Michael Huberman, and Peter H. Lindert, "A British Food Puzzle, 1770-1850," Economic History Review 48, no. 2 (1995): 233.

37. Allen, "Agricultural Productivity," 20. 
times faster than wages-in the two decades before $1789 .{ }^{38}$ In central Mexico, too, yields faltered and prices rose-maize, by nearly 50 percent-in the later eighteenth century. ${ }^{39}$ Abel dates the onset of the downturn from the 1730 s, inaugurating eighty years of rising food prices, accelerating sharply around 1770 . Across Europe, between 1730 and 1810, the price of the "chief bread grains" (wheat and rye above all) skyrocketed: "By about 250 percent in England, 205 percent in northern Italy, 210 percent in Germany, 163 percent in France, 283 percent in Denmark . . . , 265 percent in the Netherlands, 259 percent in Austria, and 215 percent in Sweden. In Denmark, the Netherlands, and Austria this was the highest point reached [up to this time] in the long-term ascent of prices." ${ }^{40}$ England took the lead not in output as such, but rather in its "capacity to augment output while releasing labour for employment in industry and services": in other words, in its capacity to prioritize labor over land productivity. ${ }^{41}$

This was the English moment-and a dramatic one at that-of a worldwide surge of primitive accumulation across the Atlantic world. The turning point in the English countryside was reached by 1760. The scale and tempo of parliamentary enclosure jumped sharply: a sixfold increase in the number and acreage of enclosure acts in the three decades after 1760 relative to the three decades prior. ${ }^{42}$ In the century following 1750, fully one-quarter of "England's cultivated acreage was transformed from open field, common land or waste land into private property." ${ }^{43}$ Agricultural occupational share declined .23 percent annually between 1522 and 1700 but accelerated sharply, to .35 percent a year between 1759$1801 .^{44}$ The food price spikes-or long swings, in the period 1740-1815-were

38. Olwen Hufton, "Social Conflict and the Grain Supply in Eighteenth-Century France," Journal of Interdisciplinary History 14, no. 2 (1983): 304.

39. Sonya Lipsett-Rivera, "Puebla's Eighteenth-Century Agrarian Decline," Hispanic American Historical Review 70, no. 3 (1990): 463-81; Leticia Arroyo Abad, Elwyn Davies, and Jan Luiten van Zanden, "Between Conquest and Independence: Real Wages and Demographic Change in Spanish America, 1530-1820," Explorations in Economic History 49, no. 2 (2012): 149-66.

40. Wilhelm Abel, Agricultural Fluctuations in Europe: From the Thirteenth to the Twentieth Centuries, trans. Olive Ordish (New York: St. Martin's, 1980), 197-98, emphasis added.

41. O’Brien, "Home Market," 775.

42. B. H. Slicher van Bath, The Agrarian History of Western Europe, 500-1850 A.D., trans. Olive Ordish (New York: St. Martin's, 1963), 319; Paul Mantoux, The Industrial Revolution in the Eighteenth Century (New York: Harper \& Row, 1961), 141-42; R. V. Jackson, "Growth and Deceleration in English Agriculture, 1660-1790," Economic History Review 38, no. 3 (1985): 333-51.

43. Eric B. Ross, "The Malthus Factor: Poverty, Politics and Population in Capitalist Development," Briefing 20 (Dorset: The CornerHouse, 2000); we should take care not to collapse two processes here: the "specific device of the Enclosure Act" and the "general phenomenon of agricultural concentration," Eric J. Hobsbawm, Industry and Empire: From 1750 to the Present Day (New York: Penguin, 1968), 101.

44. Calculated from Broadberry, Campbell, and van Leeuwen, "When Did Britain Industrialise?," 23. 
therefore not only biophysical and "economic," but, also and at the same time, pivotal moments of the world class struggle. Long inflationary swings have been, in the long history of capitalism, moments through which the bourgeoisie deploys the power of the market-backed by the power of the state, as during the great wave of parliamentary enclosures after 1760-to redistribute value from the producers to the accumulators of surplus value. ${ }^{45}$ Income inequality, a rough proxy and effective if temporary "fix" for capital accumulation, rose sharply: the English bourgeoisie-the top 5 percent-“gained enormously at the expense of the middle and upper-middle classes" over the next century. Meanwhile, the poverty ("pauperisation") rate grew by more than 50 percent after 1759, encompassing a fifth of the population by $1801 .^{46}$

This was not the first time such a redistribution of value had occurred; the "price revolution" after 1500 also redistributed value from workers to capitalists, issuing in part from the forcible suppression of peasant and proletarian diets. ${ }^{47}$ Indeed, English per capita food consumption declined across the sixteenth and seventeenth centuries (and not only for the English): a crucial subsidy to world accumulation. ${ }^{48}$

In the conjoncture of accelerating dispossession and proletarianization combined with stagnating productivity, there were two possibilities. One was that rising food prices would drive up the wage bill for capital, enacting a kind of wage squeeze on accumulation. The other was the road of forced underconsumption, whereby working-class food budgets were instead squeezed. This probably resulted in a net caloric and certainly nutritional decline for proletarian diets-at least in England but probably well beyond. ${ }^{49}$ The proposition finds support in declining physical

45. Michael Turner, Enclosures in Britain, 1750-1830 (London: Palgrave Macmillan, 1984). For Allen, the parliamentary enclosures of the late eighteenth century may be understood as a political process aimed at effecting "a massive redistribution of income from farmers to landowners" (Robert C. Allen, "The Efficiency and Distributional Consequences of Eighteenth Century Enclosures," Economic Journal 92 [1982]: 937). Nitzan and Bichler make the theoretical point: "inflation is a conflictual process of redistribution ... [T] [Te inflationary struggle isn't simply a tug-of-war between 'independent' individuals or groups in society. It is an entire regime, an encompassing political process of transforming capitalist power; see Jonathan Nitzan and Shimshon Bichler, Capital as Power: A Study of Order and Creorder (London: Routledge, 2009), 361.

46. Peter H. Lindert and Jeffrey G. Williamson, "Reinterpreting Britain's Social Tables, 1688-1913," Explorations in Economic History 20, no. 1 (1983): 104, 101.

47. Fernand Braudel and Frank Spooner, "Prices in Europe from 1450 to 1750," in The Cambridge Economic History of Europe, vol. 4, ed. E. E. Rich and C. H. Wilson (London: Cambridge University Press, 1967), 378-486; Immanuel Wallerstein, The Modern World-System I: Capitalist Agriculture and the Origins of the European World-Economy in the Sixteenth Century (New York: Academic Press, 1974).

48. Allen, "Tracking," 216-17.

49. O’Brien, "Home Market"; Allen, "Tracking." 
stature in the half century after $1760 .^{50}$ What bears emphasizing is that the redistribution of value through food price movements is a middle-run strategy. Consumption can only be driven down so far. At some point, the world-ecological surplus - the mass of unpaid work/energy relative to the mass of accumulated capital-must be expanded and not simply maintained. New frontiers must be opened, their "free gifts" identified and mapped, secured, and appropriated.

How was cheap food restored after 1815? In a word, America.

\section{NORTH AMERICA: THE TWO REVOLUTIONS}

\section{OF INDUSTRIAL AGRICULTURE}

The crucial difference between the early nineteenth and early twenty-first centuries is this. In the "long" nineteenth century (ca. 1763-1914), cheap food could be reestablished. Today it cannot. The nineteenth century restoration of cheap food occurred through a combination of "productivity and plunder": new technical innovations, such as the steamship, railroads, and mechanization, combined with an extraordinary frontier movement in North America. ${ }^{51}$ The breadbasket of capitalism would migrate, from Europe to the United States. This was an extraordinary development in human history; no civilization had relocated its agricultural heartland from one continent to another. This transition would be the work of the "first" nineteenth century (ca. 1763-1830s).

It was an era of profound chaos and restructuring during which a new configuration of town and country emerged, "dripping with blood and dirt" (as Marx would say). Peasants across the Atlantic world revolted against movements "from above" aimed at deepening capital's hegemony over the global countryside, ranging from Pugachev's revolt in Russia to a series of "backcountry" rebellions in North America. ${ }^{52}$ Nowhere was this more significant than in the nascent United States, whose modern political form takes shape through the

50. John Komlos "Shrinking in a Growing Economy? The Mystery of Physical Stature during the Industrial Revolution," Journal of Economic History 58, no. 3 (1998): 779-802; Francesco Cinnirella, "Optimists or Pessimists? A Reconsideration of Nutritional Status in Britain, 1740-1865," European Review of Economic History 12, no. 3 (2008): 325-54.

51. Centrally, but also comprising cash-crop expansions via white settler colonialism worldwide. See especially Philip D. McMichael, Settlers and the Agrarian Question: Capitalism in Colonial Australia (Cambridge: Cambridge University Press, 1984).

52. Immanuel Wallerstein, The Modern World-System III: The Second Era of Great Expansion of the Capitalist World-Economy, 1730-1840s (San Diego: Academic Press, 1989), 193-256; Thomas P. Slaughter, The Whiskey Rebellion (Oxford: Oxford University Press, 1986); C. A. Bayly, The Birth of the Modern World, 1780-1914: Global Connections and Comparisons (Malden, MA: Blackwell), 86-120. 
Constitutional settlement of 1789, prompted by Shay's Rebellion (1786). For the creation of strong centralized state was fundamental to the creation of a geographical regime-codified through successive Northwest Ordinances in the 1780s - that ensured the expanded reproduction of bourgeois property across the continent. ${ }^{53}$ Thus do the class struggle, political geography, and agricultural revolution form an organic whole in successive eras of capitalist development.

It is no accident that industrial and agricultural revolutions unfold in combined-if uneven-fashion. The full flower of English industrialization (1840s1870s) occurred at the very moment of the rise of the American Midwest as the breadbasket of capitalism. Harriet Friedmann ably charts the nexus of nature, capital, and cultivation at the dawn of this new, American-led, agricultural revolution. By the 1840s,

European settlers finally broke the matted grasses with a steel plow, invented and manufactured by John Deere. . . The plow was drawn by animals, more like European farming than that of indigenous people. The draft animals of settlers and, the cattle herded by cowboys, filled the niche of the slaughtered native buffalo. Both exotic crops and animals had to be fenced. Lacking wood in the treeless plains, fencing awaited the invention of barbed wire. Dwellings . . required the import of lumber. Plows, land, animals, materials to construct and enclose farms, all came from outside the farm and even the region. Cash was therefore scarcer and more pressing than natural fertility. Transplanted exotic humans were compelled from the beginning to grow and sell as much as possible. Mining the nutrients accumulated by nature over thousands of years, settler farmers, cowboys and ranchers could sell the products of transplanted species back to the Old World at cut-rate prices. However, soil that is not renewed is depleted. Settlers were more deeply embedded in markets than in the earthly cycles of the Great Plains. ${ }^{54}$

These earthly cycles were, however, not abolished but joined in a new synthesis. The history of agriculture is a coproductive, world-ecological affair: a history of how humans make the rest of nature, and of how nature as a whole makes

53. Parenti, "Environment Making State."

54. Harriet Friedmann, "What on Earth Is the Modern World-System? Foodgetting and Territory in the Modern Era and Beyond," Journal of World-Systems Research 6, no. 2 (2000): 491-92; also William Cronon, Nature's Metropolis: Chicago and the Great West (New York: Norton, 1991). 
human organization. That such coproduction is regularly forgotten, in the myth of humanity's separation from nature, is an accomplishment of the cheap food regime: "by linking and integrating the products [and relations] of so many ecosystems and communities, [it] obscured the very connections it helped create." 55 The new synthesis, specific to the era of large-scale industry and its heirs, was agroindustrialization, or simply "industrial agriculture" —in both its symbolic and material forms. ${ }^{56}$ The first of two great phases of agroindustrialization begins in the decades before the Civil War, not only feeding England but propelling American industrialization-beyond textiles, and in the capital-goods sector-after $1840 .^{57}$

And yet, agroindustrialization was more than a technical affair. It was, pivotally, about deploying power, capital, and science to appropriate the wealth of the continent. The extraordinary accomplishment of American capitalist agriculture in the nineteenth century is found in its harnessing of continental space as central to rising labor productivity. Here was an agricultural revolution with few gains in land productivity: yields per hectare were the same for maize and wheat in 1930 as they were in $1870 .{ }^{58}$ Labor productivity, however, surged, especially for cereal crops. Labor time in maize cultivation fell by nearly two-thirds in preharvest work and by one-half in harvesting between 1840 and $1900,{ }^{59}$ and continued to fall over the next three decades. ${ }^{60}$ Off-farm revolutions in transport magnified productivity gains yet further. ${ }^{61}$

Although "biological innovation" and mechanization were responsible for a considerable measure of this advance, the decisive variable was the blood and dirt of the frontier. On the one hand, this frontier was made possible by an extraordinary mix of violence and spatial rationalization-not only clearing the land of troublesome natives, but imposing a spatial grid that made the continent legible for capital accumulation, for which modern property relations are quite useful. ${ }^{62}$

55. Cronon, Nature's Metropolis, 256-57.

56. Weis, Global Food Economy, and The Ecological Hoofprint (London: Zed, 2013).

57. Charles Post, The American Road to Capitalism: Studies in Class-Structure, Economic Development and Political Conflict, 1620-1877 (Leiden: Brill, 2011); Brian Page and Richard Walker, "From Settlement to Fordism: The Agro-industrial Revolution in the American Midwest," Economic Geography 67, no. 4 (1991): 281-315.

58. Jack R. Kloppenburg, Jr., First the Seed: The Political Economy of Plant Biotechnology, 1492-2000 (Cambridge: Cambridge University Press, 1988), 89.

59. William N. Parker, Europe, America, and the Wider World: Essays on the Economic History of Western Capitalism (Cambridge: Cambridge University Press, 1991), 160, 174.

60. Gene Smiley, "US Economy in the 1920s," in EH.Net Encyclopedia, ed. Robert Whaples (2004), accessed June 3, 2014, http://eh.net/encyclopedia/the-u-s-economy-in-the-1920s/.

61. Douglas C. North, The Economic Growth of the United States, 1790-1860 (New York: Norton, 1966).

62. Parenti, "Environment Making State." 
Hence, the centrality of the American state in making this agricultural revolution possible. On the other hand, the frontier offered up millennia of accumulated nutrients (and water), which sustained the radical advance of the "industrial" agricultural model in the closing decades of the nineteenth century. Western Kansas wheat farmers in the 1870s enjoyed labor productivity that outstripped some European cultivators by an order of magnitude. ${ }^{63}$ But within two decades, land productivity began to decline in western Kansas. By the 1920s yields per acre were between one-quarter and one-half of the 1890s peak. ${ }^{64}$ Nevertheless, labor productivity continued to rise. ${ }^{65}$ But, as the Great Depression made clear, labor productivity would need to advance even faster in the decades to come. This "first" industrial agriculture was exhausted less for internal than for external reasons. If the first (American) agroindustrial model had consolidated Britain as the workshop of the world, a new agroindustrial model would have to be found for the consolidation of America as the world's assembly line.

This new model would be found in a new configuration of capitalization and appropriation, taking shape in the 1930s with the introduction of hybrid maize and new, higher-yielding, strains of wheat. ${ }^{66}$ The Green Revolution's core synthesis brought together the nineteenth century's dynamic family farm model with hybrid maize, the biological pivot of a new property regime. The commercial introduction of hybrid maize in the United States in the mid-1930s promised not only rising yields per acre but also rising capitalization through mechanization and skyrocketing fertilizer (and then pesticide) use. The new maize worked for capital through a paradoxical combination of high-yield seed that produced "lowyield" offspring: the inbreeding of hybridized maize variants produced sharp declines in the second generation. Seed saving gave way to seed shopping. ${ }^{67}$ The millennial relation between seed and grain had been severed, replaced with the cash nexus. ${ }^{68}$ In this, hybridization joined agroecology and market discipline in a new, higher synthesis: the "petrochemical-hybrid complex." 69

63. Geoff Cunfer and Fridolin Krausmann, "Sustaining Soil Fertility: Agricultural Practice in the Old and New Worlds," Global Environment 4 (2009): 29-30.

64. Ibid., 30; Geoff Cunfer, "Manure Matters on the Great Plains Frontier," Journal of Interdisciplinary History 34, no. 4 (2004): 539-67.

65. Parker, Europe, America.

66. Kloppenburg, First the Seed.

67. Jean-Pierre Berlan and Richard C. Lewontin, "The Political Economy of Hybrid Corn," Monthly Review 38, no. 3 (1986): 35-47.

68. Kloppenburg, First the Seed.

69. Richard Walker, The Conquest of Bread: 150 Years of Agribusiness in California (New York: New Press, 2004), 150-51. 
The magic of this Green Revolution was found in an old script with a new twist. The potential of the hybrid revolution was amplified by massive statefunding of university-led agricultural research, with origins in the late nineteenth century, and a new phase of capitalization that included mechanization but went far beyond. The capitalization of agriculture advanced as never before: "labor inputs" fell by more than two-thirds, and mechanization rose 213 percent, between 1935 and 1970. Fertilizer and pesticide inputs increased by an extraordinary 1,338 percent. $^{70}$ The globalization of this model-systematically combining "new plants, fertilizers, pesticides, and irrigation schemes" ${ }^{\prime 71}$ - soon followed, a decisive moment in the agrarian class struggles and geopolitics of the Cold War. ${ }^{72}$ And yet, in this "long" Green Revolution, the decisive geographical shift was only secondarily global-if by the term we implicate the surface of the earth. The really revolutionary act of the long Green Revolution was its subterranean thrust, drawing forth cheap energy and cheap water from the earth. After 1935, farming was no longer just farming. It was petro-farming. ${ }^{73}$

The epoch-making geographical shift after the 1930s was, consequently, quite distinctive. Petro-farming allowed for a combination of frontiers-global and subterranean-to come into play. This was a quantum expansion in the repertoire of strategies we may call accumulation by appropriation. ${ }^{74}$ It multiplied the sources of potential unpaid work/energy as never before. The decisive shift was from inputs drawn primarily within farming regions to energy- and chemical-intensive inputs drawn from outside. This marked the great fertilizer and pesticide-herbicide revolution. Two important transitions in capitalist agriculture followed. First, capitalist agriculture became massively inefficient in its use of energy. Although long implicit in capitalist agriculture, the "second" American agricultural revolution after 1935-year zero of the long Green Revolution-exploded the labor/land energy budgets of the previous four centuries. It took about 2.5 calories of energy to deliver a calorie of food in the 1930s. From that date, the ratio moved sharply

70. Calculated from Willard W. Cochrane, The Development of American Agriculture: A Historical Analysis (Minneapolis: University of Minnesota Press, 1979), 130-31.

71. Walker, Conquest, 150-51.

72. David A. Sonnenfeld, “Mexico's 'Green Revolution,' 1940-1980: Towards an Environmental History," Environmental History Review 16, no. 4 (1992): 28-52; Harry Cleaver, "The Contradictions of the Green Revolution," American Economic Review 62, no. 2 (1972): 177-86; John H. Perkins, Geopolitics and the Green Revolution: Wheat, Genes, and the Cold War (Oxford: Oxford University Press, 1997).

73. Walker, Conquest, 151.

74. Moore, "Transcending," and Web of Life. 
upward, to $7.5: 1$ in the 1950s and to $10: 1$ by the early 1970 s. ${ }^{75}$ By the twenty-first century, 15-20 calories were needed to deliver one calorie of food from farm to table, and considerably more than this for globally sourced fresh fruit. ${ }^{76}$ Any epoch-making extension of this model today will depend on locating new sources of cheap energy that not only replace declining supply zones but significantly expand those sources. Capitalism is no steady-state system; replacement is insufficient.

The second great transition inaugurated by the long Green Revolution was toxification. For the first time, the leading edge of toxification shifted toward agriculture. The massive increase in pesticide and herbicide production-an order of magnitude increase between 1950 and 1980-has made agriculture a vanguard agent of toxification. ${ }^{77}$ For many years, the poster child for this toxification was DDT (dichloro-diphenyl-trichloroethane). Some 1.3 billion pounds of this pesticide-and powerful carcinogen-were used in the United States following DDT's introduction to agriculture in 1945 until it was banned in $1972 .{ }^{78}$ Here my sense is that many of the most significant effects of massive pesticide use-one billion pounds a year in American agriculture-have yet to be fully realized. ${ }^{79}$ A half century after Rachel Carson sounded the alarm, the accumulation of pesticide and herbicide toxification may be reaching a bifurcation point. ${ }^{80}$ Causing widespread, and increasing, harm to human health, pesticide poisoning directly affects over 40 million people every year. ${ }^{81}$ This figure, however, surely underestimates

75. David, Pimentel, L. E. Hurd, A. C. Bellotti, M. J. Forster, I. N. Oka, O. D. Sholes, and R. J. Whitman, "Food Production and the Energy Crisis," Science 182, no. 4111 (1973): 443-49; John S. Steinhart and Carol E. Steinhart, "Energy Use in the U.S. Food System," Science 184, no. 4134 (1974): 307-16.

76. Thomas L. Acker, Chelsea Atwater, and Dean Howard Smith, "Energy Inefficiency in Industrial Agriculture," Energy Sources, Part B: Economics, Planning, and Policy 8, no. 4 (2013): 420-30; P. Canning, A. Charles, S. Huang, K. R. Polenske, and A. Waters, Energy Use in the U.S. Food System, Economic Research Report Number 94 (Washington, DC: United States Department of Agriculture, 2010).

77. David Tilman, Kenneth G. Cassman, Pamela A. Matson, Rosamond Naylor, and Stephen Polasky, "Agricultural Sustainability and Intensive Production Practices," Nature 418, no. 6898 (2002): 671-77.

78. Environmental Protection Agency, DDT: A Review of Scientific and Economic Aspects of the Decision to Ban Its Use as a Pesticide (Washington, DC: United States Department of Commerce, 1975), accessed July 16, 2014, http://www2.epa.gov/sites/production/files/documents/DDT.pdf.

79. Christopher D. Cook, "The Spraying of America," Earth Island Journal (Spring), accessed July 16, 2014, http://www.earthisland.org/journal/index.php/eij/article/the_spraying_of_america/.

80. Rachel Carson, Silent Spring (New York: Houghton Mifflin, 1962).

81. Angus Wright, The Death of Ramon Gonzalez: The Modern Agricultural Dilemma (Austin: University of Texas Press, 1990); WenJun Zhang, FuBin Jiang, and JianFeng Ou, "Global Pesticide Consumption and Pollution: With China as a Focus," Proceedings of the International Academy of Ecology and Environmen- 
the extent of the problem, not least the pesticide-cancer link in core as well as periphery. ${ }^{82}$ Although the translation of such externalities into the register of accumulation is imprecise, ${ }^{83}$ their scale is impressive, totaling nearly $\$ 17$ billion in unpaid costs for American agriculture in the early twenty-first century. ${ }^{84}$ This is a kind of "ecosystem services" in reverse. The capitalist mode of calculation favors, however, yet more toxification, barring a political response: $\$ 17$ billion in hypothetical costs, reckoned as externalities, is a paper tiger in the face of an estimated $\$ 33$ billion in annual weed-mediated losses ${ }^{85}$ - losses that promise to increase rapidly apace with galloping climate change.

\section{THE RISE OF NEGATIVE VALUE}

Today, the long Green Revolution that commenced in the 1930s has exhausted itself. Exhaustion does not usually entail the collapse of production. Sugar is still grown on Barbados, silver still mined in Potosí. Rather, the exhaustion of the

tal Sciences 1, no. 2 (2011): 125-44; Pesticide Action Network Asia and the Pacific, Communities in Peril: Global Report on Health Impacts of Pesticide Use in Agriculture (Manila: Pesticide Action Network Asia and the Pacific.

82. J. S. Thakur, B. T. Rao, A. Rajwanshi, H. K. Parwana, and R. Kumar, "Epidemiological Study of High Cancer among Rural Agricultural Community of Punjab in Northern India," International Journal of Environmental Research and Public Health 5, no. 5 (2008): 399-407; Debra Steingraber, Living Downstream: An Ecologist Looks at Cancer and the Environment (New York: Vintage, 1997).

83. Environmentally driven cancers of course extend well beyond the agropesticide complex, which is nevertheless quite expressive of the general problem. To what extent the cancer epidemic charted by Devra Davis (The Secret History of the War on Cancer [New York: Basic Books, 2007]) represents a growing cost to the reproduction of labor-power may be partially read through the growth of "cancer-industrial complex" and especially its Big Pharma wing (Barbara Ehrenreich, "Welcome to Cancerland," Harper's, November 2001, 43-53). Cancer care costs in the United States were \$127.6 billion in 2010 (National Cancer Institute, "Cancer Prevalence and Cost of Care Projections" [201 1], accessed May 29,2014 , http://costprojections.cancer.gov/). Why so little attention to cancer prevention?, asked one NIHfunded study: "The economic reasons loom largest. . . . There are extraordinary profits in the pharmaceutical industry in general, and chemotherapeutic drugs currently in use or on the horizon are some of the most profitable. A Forbes magazine story in 2004 quoted a clinician at a cancer treatment center in New York as saying that ten years earlier, he could extend the life of one of his patients by 11.5 months on average with a drug that cost \$500; in 2004, he could extend the life of a patient with the same diagnosis 22.5 months, at a cost of $\$ 250,000$. The goal of many current cancer treatment protocols is to repeat this experience with more and more types of cancer. Targeted chemotherapy . . . is the Holy Grail of pharmaceutical companies, and the number of people living with cancer in the U.S. is expected to double in the next two decades. These trends are likely to greatly increase profits in this industry. Those who seek to prevent or reduce the magnitude of these profits risk being swept aside by industry representatives and their political and scientific spokespeople" (Richard W. Clapp, Molly M. Jacobs, and Edward L. Loechler, "Environmental and Occupational Causes of Cancer," Reviews on Environmental Health 23, no. 1 [2008]: 25).

84. Erin M. Tegtmeier and Michael D. Duffy, "External Costs of Agricultural Production in the United States," International Journal of Agricultural Sustainability 2, no. 1 (2004): 1-20.

85. Tom Christopher, "Can Weeds Help Solve the Climate Crisis?," New York Times, June 29, 2008. 
Green Revolution signifies the erosion of the model's capacity to deliver a rising stream of unpaid work/energy into commodity production. ${ }^{86}$ Agrobiotech's promise to restore cheap food has fizzled. Such exhaustion is not novel, of course. We have seen it many times before. The exhaustion of English agriculture in the eighteenth century didn't mean they stopped growing wheat. It did mean, however, that English agriculture no longer sustained cheap food.

What needs to be explained is agrobiotech's nonrevolution: no reversal of yield deceleration, ${ }^{87}$ no net gain in food security. ${ }^{88}$ "Dispossession" has registered so strikingly in radical discourse precisely because neoliberalism's agrarian transformations redistributed power and wealth from poor to rich without a productivity revolution. ${ }^{89}$ World agricultural productivity growth slowed from 3 percent a year in the 1960s to just 1.1 percent in the 1990s. ${ }^{90}$ This tells us something important about capitalist technological dynamism today. Absent the identification and appropriation of significant new streams of unpaid work/energy, technology is unable to deliver significant advances in labor productivity. Here the long Green Revolution mirrors the systemwide deceleration of labor productivity growth since the 1970s. ${ }^{91}$ But the situation is more explosive than a resource- and nutrientdepletion model suggests. On the one hand, the usual agrocapitalist technical fixes-or attempted fixes-are undermining whatever possibilities might remain for a new round of world accumulation. These movements reinforce extant tendencies toward nutrient and resource depletion: running down nature as "tap." On the other hand, the ongoing closure of the "waste frontier" —whose decisive expression is climate change-is activating a new set of limits, swirling around nature as "sink." 92

86. See Moore, "Cheap Nature."

87. David Gurian-Sherman, Failure to Yield: Evaluating the Performance of Genetically Engineered Crops (Cambridge, MA: Union of Concerned Scientists, 2009).

88. "Broadly speaking, countries making a substantial shift to GM crops are in a group where food security has either shown no improvement (e.g., the United States) or where it is declining (e.g. Argentina)"; United Nations Commission on Trade and Development, Wake Up before It's Too Late: Make Agriculture Truly Sustainable Now for Food Security in a Changing Climate (New York: United Nations, 2013), 206.

89. David Harvey The New Imperialism (Oxford: Oxford University Press, 2003); Moore, "End of the Road?"; GRAIN, Hungry for Land.

90. Richard Dobbs, Jeremy Oppenheim, Fraser Thompson, Marcel Brinkman, and Marc Zornes, Resource Revolution (New York: McKinsey Global Institute, 2011), 27.

91. Gopal Balakrishnan, "Speculations on the Stationary State," New Left Review II/59 (2009): 5-26; Robert J. Gordon, “Is US Economic Growth Over?," Working Paper 18315 (Washington, DC: National Bureau of Economic Research, 2012), accessed January 14, 2014, http://www.nber.org/papers/w18315.

92. The outlines of this argument are suggested by Christian Parenti, "The Book That Launched a Movement," The Nation, December 24/31 (2012): 24-26. 
This contradiction-between nature-as-tap and nature-as-sink-is issuing limits of a new sort: the limits of negative value. ${ }^{93}$ From the beginning, modernity's Cheap Nature strategy has been premised on a trinity of specific projects: (1) the deployment of juridical, cartographic, and quantitative procedures to map, secure, and code Nature with a capital "N"; (2) the rationalization of production, as with monocultures and assembly lines, to "simplify" nature within the sphere of production; (3) the extraction of as much work/energy as fast as possible, for the lowest possible capital expenditure. Taken together, these interwoven projects-creating "economies" of rationalization, control, and speedhave combined to do something more than facilitate high-profit primary production complexes. They have worked to reduce the costs of production for capital as a whole. The linchpin of the whole strategy was capital's capacity to expand its appropriation of unpaid work/energy faster than the capitalization of global nature.

Negative value can be understood as the accumulation of biophysical limits to capital in the web of life that are now fettering the restoration of the Four Cheaps: food, labor power, energy, and raw materials. ${ }^{94}$ Historically, the accumulation of negative value assumed a latent or potential form. Over the past few decades, it has been activated through late capitalism's marriage of productivism, global trade and transport, and toxification. The recent history of invasive flora and fauna is suggestive of a dramatical shift. Capitalism was, as we know, built on invasive species and diseases: the Columbian Exchange. ${ }^{95}$ Five centuries later, the annual losses from invasive species are counted in the hundreds of billions of dollars ... and rising. ${ }^{96}$ This is the transition from latent to active negative value, generating a torrent of unpredictable socioecological problems that are, increasingly, stressing the widening fissures of capitalist power and production. The contradictions are immediate, direct, and deepening in the early twenty-first century.

The accumulation of negative value is a way to think about modernity's limits as coproduced through the accumulation of capital and the production of nature.

93. In this, Foster comes close conceptually-without altering his social reductionist model of capitalism—to the present argument: "The accumulation of capital is at the same time the accumulation of catastrophe, not only for a majority of the world's people, but living species generally," John Bellamy Foster, "Capitalism and the accumulation of catastrophe," Monthly Review 63, no. 7 (2011): 16, emphasis added.

94. Moore, "Cheap Food."

95. Alfred W. Crosby Jr., The Columbian Exchange: Biological and Cultural Consequences of 1492 (New York: Academic Press, 1972).

96. George Marbuah, Ing-Marie Gren, and Brendan McKie, "Economics of Harmful Invasive Species," Diversity 6, no. 3 (2014): 500-523. 
It should be not confused with a broader set of so-called environmental problems arising from nutrient depletion. There are two main reasons for this. First, negative value transcends the boundaries of the human and extrahuman. Second, active negative value intrudes directly into the costs of production and therefore cannot be externalized. Negative value, from this perspective, is bound up with, but not reducible to, the externalization of costs and the social movements-environmentalism above all-that have developed in response to this externalization since the 1970s.

Understanding the capital relation as itself coproduced in and through the web of life entails a conceptualization of capital's internal crises as coproduced. The rising organic composition of capital, broadly conceived, entails the rising capitalized composition of global nature. ${ }^{97}$ The progressive capitalization of nature, in turn, activates negative value in the absence of new frontiers. While the rising organic composition of capital generates a tendency toward a declining rate of profit, the capitalization of nature generates a new set of problems. These problems, as I will try to make clear, combine the old and the new: in part resource depletion and rising costs of production also. ${ }^{98}$ But in part-and a rising part at thata destabilization of the conditions of biospheric stability and biological health that have obtained for centuries, even millennia.

This destabilization of biospheric and biological health is internalized by capital today because frontiers of sufficient size and scope are no longer available. Ongoing destabilization, moreover, makes it increasingly improbably that new sources of work/energy can be found. Ongoing and impending biospheric "state shifts" 99 are finding expression in the contradictions immanent to the production and realization of surplus value. The contradictions can be understood in an expanded frame that stresses the nonidentity of the substance of value (abstract social labor) and the relations of "paid" and "unpaid" work/energy necessary to sustain value accumulation. ${ }^{100}$ Here I take socially necessary labor time to be determined through a dialectic of capitalization and appropriation. The first moment works through organizational and technical innovation within the circuit of capital. The second momentappropriation-works through the extraeconomic mobilization of unpaid work/energy in service to the rate of exploitation. The lifeblood of socially necessary labor time

97. Moore, "Transcending," and Web of Life.

98. See esp. Clive Ponting, A Green History of the World (New York: St. Martin's, 1991); O'Connor, Natural Causes.

99. Anthony D. Barnosky et al., "Approaching a State Shift in Earth's Biosphere," Nature 486 (2012): 52-58.

100. Moore, Web of Life, and "Capitalocene, Part II." 
is socially necessary unpaid work. Negative value emerges in-and transcendsboth zones, of capitalization and of appropriation. Superweeds frustrate cash-crop monocultures. Global warming undermines the conditions of capital accumulation.

From this perspective, surplus value and negative value are immanent contradictions, operating with distinctive temporalities. The course of surplus-value production produces latent negative value from day 1 of capitalism. The transition from latent to active negative value occurs as commodity frontiers recede and waste frontiers fill up, a process that I will chart presently.

Negative value, then, stands as a preliminary concept through which to situate three problems in a unified frame: (1) the ongoing, and impending, nonlinear shifts of the biosphere and its biological systems; (2) the rising costs of production; and (3) the overaccumulation of capital. These three moments represent a bundle of contradictions within capital that provide fertile ground for a new radical politics that challenges capitalism on ontological grounds: questioning the practical viability, yes, of capitalist markets and production, but more fundamentally, the ontology of value and nature in the modern world system. In the second half of this article, we follow these contradictions of global value relations, the rise of negative value, and their connections to the rise of a new ontological politics of food, agriculture, and nature.

\section{NATURE-AS-TAP, NATURE-AS-SINK: NEGATIVE VALUE'S COMBINED AND UNEVEN DEVELOPMENT}

The "normal" course of capitalist technological dynamism is not only failing to resolve the energy, nutrient, and resource problems it faces. These problems are dramatically worsening out of all proportion to any linear expectation. Why? Because there is a cumulative dimension to primary production: high "rewards" with minimal "effort" and low environmental impact yield to nonlinear curves of declining rewards and rising effort, implicating dramatically greater environmental changes. ${ }^{101}$ Contrast an Oklahoma cricket pump in the 1930s with offshore drilling in Gulf of Mexico today. The world-historical arc of the long Green Revolution reveals a similar process: more and more herbicides and fertilizers are necessary to produce each increment of (decelerating) productivity growth.

The cumulative and cyclical dimensions of nature-as-tap-expressed through successive scientific, extractive, and agricultural revolutions-are now meeting

101. Debra J. Davidson, Jeffrey Andrews, and Daniel Pauly, “The Effort Factor: Evaluating the Increasing Marginal Impact of Resource Extraction Over Time," Global Environmental Change 25 (2014): 63-68. 
up with the cumulative dimension of nature-as-sink. Every great movement of appropriating new streams of unpaid work/energy implies a disproportionately larger volume of waste. The waste accumulates, but worse, undergoes a cascading series of toxic transformation. Value and waste are therefore dialectically bound, in a cumulatively disproportionate relation. Agriculture, however, was relatively immune from this tendency until fairly late in the game. Not until the advent of the long Green Revolution did agriculture assume a leading role in toxification, flooding soils, water, and air with the effluents of petrofarming. Urbanization, mining, and industry had been generating a rising volume of wastes since the sixteenth century, when contemporaries observed poisoned streams and befouled air amidst the mining boomtowns of central Europe. ${ }^{102}$ The globalization of the Green Revolution through American-led developmentalism-and then neoliberal restructuring-changed that. Agriculture has now moved to the pole position in the race to pollute the earth-in part because of its energy and chemical intensity, but also because its role in land clearance removes forests that would otherwise lock up carbon. ${ }^{103}$

Capitalism's double squeeze on taps and sinks has been recognized-especially in relation to climate change ${ }^{104}$ _but I think its epochal implications are underappreciated, in at least two major ways. One is that waste production is overflowing the sinks to such a degree that toxification is now spilling over onto the ledgers of capital. Climate change, once again, is our "thickest," most expressive instance of this general law. The connection between biospheric "state shifts" and accumulation crisis is much more intimate than dominant redgreen thinking allows. ${ }^{105}$

But I think there is another, deeper, historical-geographical problem that has not (yet) been sufficiently considered in relation this double squeeze. This problem turns on the distinctive temporalities of nature-as-tap and nature-as-

102. John U. Nef, The Conquest of the Material World (New York: Meridian, 1964); Georgius Agricola, De Re Metallica, trans. Herbert Clark Hoover and Lou Henry Hoover (1556; New York: Dover, 1950).

103. Timothy Herzog, "World Greenhouse Gas Emissions in 2005," WRI Working Paper (July) (Washington, DC: World Resources Institute, 2009), accessed July 4, 2014, http://www.papierenkarton .nl/uploads/world_greenhouse_gas_emissions_2005.pdf.

104. Brett Clark and Richard York, "Carbon Metabolism: Global Capitalism, Climate Change, and the Biospheric Rift," Theory and Society 34, no. 4 (2005): 391-428.

105. "There is no purely economic reason that capitalism as a system might not continue indefinitely despite its manifest failures and contradictions"; John Bellamy Foster (as "Editors"), "Notes from the Editors," Monthly Review 58, no. 1 (2007), http://monthlyreview.org/2007/03/01/march-2007-volume -58-number-10, emphasis added. 
sink. ${ }^{106}$ New primary production regimes, until now, could develop much faster than the contradictions of externalizing costs onto the backs and blood of human and extrahuman natures. Outrunning these contradictions was possible because there were geographical frontiers-not just continents, but bodily, subterranean, and atmospheric spaces-from which "free gifts" could be extracted, and "free garbage" deposited.

There is, then, a fantastically nonlinear dynamic at play that has been insufficiently apprehended by students of global environmental change and global political economy. The dynamism of capitalist technological advance not only produces a tendency for industrial production to run ahead of its raw materials supply_Marx's "general law" of underproduction ${ }^{107}$ —it also produces a "general law" of overpollution: the tendency to enclose and fill up waste frontiers faster than it can locate new ones. Thus a graph of the waste accumulation curve over the longue durée would show a nonlinear slope with a series of sharp upticks after 1945, 1975, and 2008. As "resource quality"—a wretched term-declines, it is not only more costly to extract work/energy, it becomes more toxic. This is the transition from placer to cyanide gold mining, or the rising share of strip mining in world coal production. ${ }^{108}$ The result today is a world in which every nook and cranny bears the impress of capital's toxification: from heavy metals in Arctic glaciers and children's blood to the plastic "garbage patches" in the Atlantic and Pacific Oceans to rising atmospheric concentrations of $\mathrm{CO}_{2} \cdot{ }^{109}$

106. The Green strategy of treating nature as "nature in general" rather than as a series of specific configurations of humanity-in-nature has tended to produce an unproductive binary of "capitalist" and "natural" time (e.g., Andreas Malm, "The Origins of Fossil Capital," Historical Materialism 21, no. 1 [2013]: 15-68).

107. Karl Marx, Capital, ed. Frederick Engels, 3 vols. (New York: International Publishers, 1967), 119-21

108. Davidson et al., "Effort Factor."

109. Shiv Mohan Singh, Jagdev Sharma, Puja Gawas-Sakhalkar, Ajay K. Upadhyay, Simantini Naik, Shailesh M. Pedneker, and Rasik Ravindra, "Atmospheric Deposition Studies of Heavy Metals in Arctic by Comparative Analysis of Lichens and Cryoconite," Environmental Monitoring and Assessment 185, no. 2 (2013): 1367-76; Lucjan Pawłowski, "How Heavy Metals Affect Sustainable Development," Rocznik Ochrona Srodowiska 13, no. 2 (2011): 51-64; Charles Moore, "Trashed: Across the Pacific Ocean, Plastics, Plastics, Everywhere," Natural History 112, no. 9 (2003): 46-51; Marcus Eriksen et al. "Plastic Pollution in the World's Oceans: More than 5 Trillion Plastic Pieces Weighing over 250,000 Tons Afloat at Sea," PLoS ONE 9, no. 12 (2014): el11913; Richard A. Lovett, "Huge Garbage Patch Found in Atlantic Too," National Geographic News, March 2, 2010, accessed July 29, 2014, http://news.nationalgeographic.com /news/2010/03/100302-new-ocean-trash-garbage-patch/; Glen P. Peters, Gregg Marland, Corinne Le Quéré, Thomas Boden, Josep G. Canadell, and Michael R. Raupach, "Rapid Growth in $\mathrm{CO}_{2}$ Emissions after the 2008-2009 Global Financial Crisis," Nature Climate Change 2, no. 1 (2012): 2-4. 
This unsavory convergence-of nature-as-tap and nature-as-sink-is dramatically undermining the possibility for "normal" capitalism to survive, over the medium run of the next 20-30 years. The contradictions of capitalism have always-until the early twenty-first century-been escapable, because there were escape hatches: peasantries to be proletarianized, new oil fields to exploit, new forests to convert to cash-crop agriculture. These processes continue, albeit under progressively more ruthless conditions. What merits our attention todayand what many Greens, unduly focused on what capitalism does to nature (the degradation question) rather than how nature works for capitalism (the work/ energy question), have overlooked-is how capital is throwing up limits of an entirely new character.

These are the limits that issue from the production of negative value.

These new limits signal the emergence of forms of nature that are increasingly hostile to capital accumulation, and that can be temporarily fixed (if at all) only through increasingly costly, toxic, and dangerous strategies. The rise of negative value-latent for much of capitalist history - therefore suggests a significant and rapid erosion of opportunities for the appropriation of new streams of unpaid work/energy. As such, these new limits are qualitatively different from the nutrient and resource depletion of earlier, developmental crises of the Cheap Food model. Depletion remains, but now reinforces negative value, a signal that we are facing an epochal crisis impossible to resolve within the Cheap Nature model.

The concept of negative value finds inspiration from Custer's important articulation of "negative use-value": a concept that encompasses "the detrimental health and environmental consequences of capitalist manufacturing . . . [It seeks to] . . . facilitate a systematic assessment of capitalism's negative impact on the living earth." ${ }^{110}$ Custer does not, however, seek to root these "health and environmental consequences" as self-forming limits within the totality of the capitalist world-ecology and its value relations. He does not move beyond the consequential bias of Green thought. Nor does he see that "health and environmental consequences" are but one dimension of negative utility. For the problem is only partly one of utility. More fundamentally, it is one of the exhaustion of those relations that directly transform work/energy into capital. From the standpoint of negative value, we are tracing much more than socioecological externalities, al- 
though in a descriptive sense these externalities are indeed part of the problem. More to the point, negative value highlights the temporally proximate contradictions emerging from value relations, understood as a "double internality": value relations as simultaneously internalizing nature and internalized by nature. ${ }^{111}$ Hence: negative-value accumulation is the accumulation of capital's biophysical limits in the web of life. These limits are contradictions of capital-in-nature, propelled and expressed through the law of value.

Two major streams of negative value can be identified immediately. (These are far from the only ones, and we focus on the explicitly biospheric and biological moments as particularly expressive of the problem, not as the boundaries of the process. ${ }^{112}$ ) One is climate change. Together, world agriculture and forestry (including land clearance) contributes between one-quarter and one-third of greenhouse gas emissions-rivaling or exceeding industry or energy. ${ }^{113}$ On

111. Moore, Capitalocene, Part II," and Web of Life. On the one hand, capitalism internalizeshowever partially-the relations of the biosphere. In the process, the agencies of capital and empire (but not only these) seek to turn the work/energy of the biosphere into capital (abstract social labor). On the other hand, capital's internalization of biospheric process-which is something that all human organizations do-simultaneously shape the biosphere's internalization of capitalism's process. These are asymmetrical relations, of course, whose valences and vectors change over time. In this, the philosophical point shapes the historical observation: capitalism, like all civilizations, is constituted through a double internalization: capitalism-in-nature/nature-in-capitalism. To say human activity of any sort "organizes" nature is to say that human activity is ontologically coincident with, and constituted through, specifically bundled relations with the rest of nature. "Society" is not only a producer of changes in the web of life but also a product of it; this is the heart of a coevolutionary method in which human history is always bundled with the rest of nature (see Moore, Web of Life).

112. A fuller analysis of negative value would move beyond the immediately geobiological emphasis that I have presented, and unpack, for instance, the role of financialization in food commodity markets and in shaping global supply chains, from grain trading to supermarkets, which have the consequence of squeezing both producers and customers in the "corporate food regime." See, respectively, Kaufman, Bet the Farm; S. Ryan Isakson, "Food and Finance: The Financial Transformation of Agro-food Supply Chains," Journal of Peasant Studies 41, no. 5 (2014): 749-75; Philip McMichael, "The Land Grab and Corporate Food Regime Restructuring," Journal of Peasant Studies 39, nos. 3-4 (2012): 681-701. The financialization of agrofood relations (including the recent "land grab"), moreover, signals a new stage in the fetishization of food at the very moment when the relations of power and production in the global food system have become more transparent than ever before (see esp. Jennifer Clapp, "Financialization, Distance and Global Food Politics," Journal of Peasant Studies 41, no. 5 [2014]: 797-814). Such a line of investigation would reveal finance and farming as coproducing not only food and capital, but climate, power, and much more.

113. Intergovernmental Panel on Climate Change, Climate Change 2007: Synthesis Report (Geneva: Intergovernmental Panel on Climate Change, 2007), 36, accessed July 26, 2014, http://www.ipcc.ch /pdf/assessment-report/ar4/syr/ar4_syr.pdf; and "Summary for Policymakers," in Climate Change 2014: Mitigation of Climate Change (Geneva: Intergovernmental Panel on Climate Change, 2014), accessed January 20, 2015, http://www.ipcc.ch/pdf/assessment-report/ar5/wg3/ipcc_wg3_ar5_summary-for-policy makers.pdf. 
the one hand, climate change is reinforcing tendencies-such as the depletion of aquifers-already in motion before the 1990s. On the other hand, climate change is creating new problems: suppressing the yield of the "big four" cereals (rice, wheat, maize, and soy), changing precipitation patterns, and suppressing labor productivity during the increasingly hot summer months when most planting and harvesting occurs. ${ }^{114}$ In some cases, rising $\mathrm{CO}_{2}$ concentrations may favor certain crops-wheat or rice, for instance. ${ }^{115}$ But such productivity gains are strictly hypothetical: they will be offset by rising temperatures over the middle run of 20 years and, over the short-run, the advance of invasive weeds whose geographical range and fertility will nullify potential gains from carbon fertilization. ${ }^{116}$ Lobell and his colleagues find that between 1980 and 2008 "global maize and wheat production declined by $3.8 \%$ and $5.5 \%$, respectively, compared to a counterfactual without climate trends." ${ }^{117}$ By 2035, agriculture will bear one-third, and by 2060 two-thirds, of the global economic "damages" issuing from climate change-

114. Shaobing Peng, Jianliang Huang, John E. Sheehy, Rebecca C. Laza, Romeo M. Visperas, Xuhua Zhong, Grace S. Centeno, Gurdev S. Khush, and Kenneth G. Cassman, "Rice Yields Decline with Higher Night Temperature from Global Warming," Proceedings of the National Academic of Science 101, no. 27 (2004): 9971-75; Carlos Eduardo P. Cerri, Gerd Sparovek, Martial Bernoux, Willian E. Easterling, Jerry M. Melillo, and Carlos Clemente Cerri, "Tropical Agriculture and Global Warming: Impacts and Mitigation Options," Scientia Agricola 64, no. 1 (2007): 83-99; William R. Cline, Global Warming and Agriculture (Washington, DC: Peterson Institute for International Economics, 2007); David B. Lobell and Christopher B. Field, "Global Scale Climate-Crop Yield Relationships and the Impacts of Recent Warming," Environmental Research Letters 2, no. 1 (2007): 014002; Christopher J. Kucharik, and Shawn P. Serbin, "Impacts of Recent Climate Change on Wisconsin Corn and Soybean Yield Trends," Environmental Research Letters, 3, no. 3 (2008): 034003; A. J. Challinor, J. Watson, D. B. Lobell, S. M. Howden, D. R. Smith, and N. Chhetri, "A Meta-analysis of Crop Yield under Climate Change and Adaptation," Nature Climate Change 4, no. 4 (2014): 287-91; Joshua Zivin and Matthew Neidell, Temperature and the Allocation of Time, Working Paper, no. 15717 (National Bureau of Economic Research, Washington, DC, 2010); Kate Gordon, Risky Business: The Economic Risks of Climate Change in the United States (New York: Risky Business Project, 2014); S. Asseng et al., "Rising Temperatures Reduce Global Wheat Production," Nature Climate Change, published electronically 2014, doi: 10.1038/nclimate2470.

115. Cline, Global Warming; but see A. J. McMichael, Planetary Overload: Global Environmental Change and the Health of the Human Species (Cambridge: Cambridge University Press, 1993); Peter H. Howard and Thomas Sterner, "Raising the Temperature on Food Prices: Climate Change, Food Security, and the Social Cost of Carbon" (paper prepared for presentation at the annual meeting of the Agricultural \& Applied Economics Association, Minneapolis, July 27-29, 2014), accessed July 13, 2014, http://ageconsearch.umn .edu/bitstream/170648/2/PeterHHoward_AAEA2014_1.pdf.

116. Jerry M. Mellilo, Terese Richmond, and Gary W. Yohe, eds., Climate Change Impacts in the United States: The Third National Climate Assessment, U.S. Global Change Research Program (Washington, DC: US Government Printing Office, 2014), 142, 420; United States Department of Agriculture, Climate Change and Agriculture in the United States: Effects and Adaptation, USDA Technical Bulletin 1935 (Washington, DC, 2012), 39-40; Gordon, Risky Business.

117. David B. Lobell, Wolfram Schlenker, and Justin Costa-Roberts, "Climate Trends and Global Crop Production since 1980," Science 333, no. 6042 (2011): 616. 
in what is surely a conservative estimate offered by the Organization for Economic Cooperation and Development (OECD). ${ }^{118}$ Here is the accumulation of negative value at work: the production of direct barriers to the accumulation of capital as a whole, mediated through the climate-mediated erosion of agricultural productivity.

While no simple causal line can be drawn between climate change and particular weather events, the link between global warming, drought frequency, and global aridity is well established. ${ }^{119}$ One therefore reads with some concern about American maize production moving toward more-not less—drought sensitivity. ${ }^{120}$ It may be useful to underscore that the American Midwest is responsible for one-third of world maize output and half of world exports. ${ }^{121}$ Any serious drought in America's agricultural heartlands is therefore something of a worldhistorical event. California's recent history is illuminating in this regard. By January 2014, "nearly all of California," the country's leading agricultural state, "was in a state of extreme drought," and half of the United States suffered from drought by May, affecting " $54 \%$ of the national wheat crop, $30 \%$ of the national corn area, $22 \%$ of soya beans, $32 \%$ of hay crops and $48 \%$ of cattle." ${ }^{122}$ By the end of 2014 , we learned that California's drought was the "most severe . . . in the last 1200 years." ${ }^{123}$ While drought is not exceptional in itself, the global trend since 2001 has been toward "longer, more severe droughts," a movement with dire implications for yields ${ }^{124}$-and for rising costs of production. The bill for the 2014 drought comes

118. Henrik Braconier, Giuseppe Nicoletti, and Ben Westmore "Policy Challenges for the Next 50 Years," OECD Economic Policy Paper No. 9 (Paris: Organization for Economic Cooperation and Development, 2014), 32.

119. Aiguo Dai, "Drought under Global Warming," Climate Change 2, no. 1 (2011): 45-65. Drought has been coupled, as we know, with the increasing frequency of extreme rainfall events.

120. David B. Lobell, Michael J. Roberts, Wolfram Schlenker, Noah Braun, Bertis B. Little, Roderick M. Rejesus, and Graeme L. Hammer, "Greater Sensitivity to Drought Accompanies Maize Yield Increase in the US Midwest," Science 344, no. 6183 (2014): 516-19.

121. Donald R. Ort and Stephen P. Long, “Limits on Yields in the Corn Belt," Science 344, no. 6183 (2014): 484 .

122. NASA Earth Observatory, "Drought Stressing California's Plantscape," February 14, 2014, accessed May 19, 2014, http://earthobservatory.nasa.gov/IOTD/view.php?id=83124; United States Drought Monitor, “U.S. Drought Monitor," May 15, 2014, accessed May 18, 2014, http://droughtmonitor.unl.edu/; Suzie Horne, "US Drought Could Halve Wheat Harvest in Oklahoma," Farmer's Weekly, May 12, 2014, http:// www.fwi.co.uk/articles/12/05/2014/144492/us-drought-could-halve-wheat-harvest-in-oklahoma.htm; Walker, Conquest, 3

123. D. Griffin, and K. J. Anchukaitis, "How Unusual Is the 2012-2014 California Drought?," Geophysical Research Letters 41 (2014): 9017.

124. Philip Bump, "What's Exceptional about the Current Drought—and What Isn't," May 17, 2014, accessed May 20, 2014, http://www.washingtonpost.com/blogs/the-fix/wp/2014/05/17/whats-exceptional 
to $\$ 1.5$ billion for California agriculture alone. ${ }^{125}$ Worse still, not only do rising temperatures suppress crop and labor productivity. Rising $\mathrm{CO}_{2}$ concentrations alter the nutritional content of cereal crops in exactly the wrong direction: reducing protein, zinc, and iron content at a time when nutrient deficiencies already affect some three billion people. ${ }^{126}$

THE SUPERWEED EFFECT: NOT JUST WEEDS . .

A second stream of negative-value accumulation is more subtle but just as problematic. This is the "superweed effect": the tendency of extrahuman natures to evolve more rapidly than the technological disciplines of capitalist agriculture. ${ }^{127}$ In essence, the superweed effect signifies the coevolution of forms of work/energy that are hostile to capital accumulation and whose hostility cannot be readily blunted by the usual strategies of the "taming cycle." ${ }^{128}$

The superweed effect is at once creative and destructive. It is creative insofar as weeds- "a plant in the wrong place"- -have evolved to survive the Roundup Ready herbicides (glyphosates) that are fundamental to genetically modified soy and other crops. ${ }^{129}$ And as if to move from the frying pan to the fire, rising $\mathrm{CO}_{2}$ concentrations strongly favor a variety of invasive weeds. ${ }^{130}$ The superweeds' resistance is now calling forth a new effort by agrobiotech firms to introduce 2,4D-resistant soybeans in the United States, Brazil, Argentina, and South Africa. Perhaps best known as the key ingredient in the "Agent Orange" of the Vietnam War, 2,4-D is a known carcinogen and endocrine disruptor. If successful, this newest round of GMOs would mark a "rerun of the 1990s' introduction of

-about-the-current-drought-and-what-isnt/; Wolfram Schlenker and Michael J. Roberts, "Nonlinear Temperature Effects Indicate Severe Damages to US Crop Yields under Climate Change," Proceedings of the National Academy of Sciences 106, no. 37 (2009): 15594-98.

125. Richard Howitt, Josué Medellín-Azuara, Duncan MacEwan, Jay Lund, and Daniel Sumner, Economic Analysis of the 2014 Drought for California Agriculture, Center for Watershed Sciences, University of California, Davis, July 15, 2014, accessed July 17, 2014, https://watershed.ucdavis.edu/files/content /news/Economic_Impact_of_the_2014_California_Water_Drought.pdf.

126. Samuel S. Myers et al., "Increasing $\mathrm{CO}_{2}$ Threatens Human Nutrition," Nature 510, no. 7503 (2014): 139-42; Sharada Keats and Steve Wiggins, Non-staple Foods \& Micro-nutrient Status (London: Overseas Development Institute, 2010).

127. Moore, "Cheap Food."

128. "As control is gained within a limited sphere, the broader conditions for predictability (e.g., in agriculture) are undermined," thence renewing the cycle: with expanding quantitative and evolving quantitative dimensions" (Victor Wallis, "Species Questions," Organization and Environment 13, no. 4 [2000]: 500-507, 504).

129. Natasha Gilbert, "A Hard Look at GM Crops," Nature 497 (2013): 24-26.

130. Lewis H. Ziska, "Evaluation of the Growth Response of Six Invasive Species to Past, Present and Future Atmospheric Carbon Dioxide," Journal of Experimental Botany 54 (2003): 395-404. 
Roundup Ready (glyphosate-resistant) crops, only this time the herbicides in question are much more toxic." ${ }^{131}$ Nor is this concern merely speculative. Already, 2,4-D applications in the United States have grown apace with glyphosate (e.g., Roundup Ready) use-the former rising 90 percent between 2000 and 2012. ${ }^{132}$

Nor is the superweed effect limited to weeds. Antibiotic resistance, fueled by the meat-industrial complex and abetted by the Western medical model, has developed to such an extent that it threatens "to set medicine back a century." ${ }^{133}$ For the World Health Organization, antibiotic (properly, antimicrobial) resistance is an "impending public health crisis" ${ }^{134}$ _although one wonders just how impending it really is. As with superweeds, "superbugs" have flourished in an era of warming climate, reinforcing the contradictions of antibiotic promiscuity. ${ }^{135}$ Rising costs of "social" reproduction in this sphere are already evident. Antibiotic resistance in the USA alone is responsible for \$21-\$35 billion in additional costs, 8 million additional hospital days, and a net drag on GDP growth between 4 and 1.6 percent annually. ${ }^{136}$ So far, the marginal benefit has favored the meatindustrial complex, for whom antibiotic promiscuity returns about $\$ 2$ billion in extra profits annually. ${ }^{137}$ How long the trade-off can be sustained-even within a capitalist logic-is not clear. Fully three-quarters of "all emerging infectious

131. GRAIN, Soja 2,4-D: Waging War on Peasants, GRAIN report, 2014, accessed June 4, 2014, emphasis added; http://www.grain.org/article/entries/4945-2-4-d-soy-waging-war-on-peasants; also Charles M. Benbrook, "Impacts of Genetically Engineered Crops on Pesticide Use in the US: The First Sixteen Years," Environmental Sciences Europe 24, no. 1 (2012): 1-13.

132. Food and Water Watch, Superweeds: How Biotech Crops Bolster the Pesticide Industry (Washington, DC: Food and Water Watch, 2013).

133. "Antibiotic Resistance: The Drugs Don't Work," The Economist, May 3, 2014, http://www .economist.com/node/21601547/print.

134. WHO [World Health Organization], Antimicrobial Resistance (Paris: World Health Organization, 2014), xix

135. Lim S. Jones and Robin A. Howe, "Microbial Resistance and Superbugs," in Biofilms in Infection Prevention and Control: A Healthcare Handbook, ed. Steven L. Percival et al. (New York: Academic Press, 2014), 257-86; WHO [World Health Organization], Climate Change and Human Health-Risks and Responses (Paris: World Health Organization, 2003); Sonia Altizer, Richard S. Ostfeld, Pieter T. J. Johnson, Susan Kutz, and C. Drew Harvell, "Climate Change and Infectious Diseases," Science 341, no. 6145 (2013): 514-19; Thomas P. Van Boeckel, Sumanth Gandra, Ashvin Ashok, Quentin Caudron, Bryan T. Grenfell, Simon A. Levin, and Ramanan Laxminarayan, "Global Antibiotic Consumption 2000 to 2010 : An Analysis of National Pharmaceutical Sales Data," The Lancet Infectious Diseases 14, no. 8 (2014): 742-50.

136. Gautam Dantas and Morten O. A. Sommer, "How to Fight Back Against Antibiotic Resistance," American Scientist 102 (2014): 42-51; World Health Organization, Antimicrobial Resistance.

137. David Pimentel, "The Effects of Antibiotic and Pesticide Resistance on Public Health," in Antibiotic Resistance: Implications for Global Health and Novel Intervention Strategies, ed. Alison Mack, David A. Relman, and Eileen R. Choffnes (Washington, DC: National Academies Press, 2010), 270. 
diseases now originate in animals or animal products." ${ }^{138}$ The combination of antibiotic resistance, climate change, and global flows of human and extrahuman nature points toward disease as a significant nexus of systemic crisis in the coming decade.

The superweed effect's creativity is matched by a less obvious, but portentous, movement of destruction. In this our honeybees and the mysterious "colonycollapse disorder" is instructive. A herald of our times, nobody really understands colony collapse-it is an unpredictable, unruly, unknown vector of a crisis that everybody sees but no one (not yet, anyway) really understands. ${ }^{139}$ While some species, like our superweeds, adapt by evolving quickly in the face of new pesticides, for others, the immediate options are much more constrained. Collapse is as much a revolt against capitalist imperatives as surviving the toxic onslaught. If the proximate cause of colony-collapse disorder is not yet clear, its socioecological roots are not hard to pinpoint. As Kosek explains, capitalist beekeeping has

radically altered the structure and behavior of the hive, from logs and skips to a fully industrialized hive modeled on the modern factory. The bee's range has also been radically altered, from a radius of two miles to the migratory geography of the modern bee, who travels thousands of miles of on the back of semi-trucks and is fed on corn syrup and soy protein supplements in order to pollinate single crops for eight weeks at a time. . . . But probably the most important change for contemporary beekeeping was the unprecedented portability and management of the hive in ways that had not previously been possible. This mobility in turn allowed for the rise of the industrial geography of beekeeping, in which 80 percent of the hives in the US are now trucked around the country, serving the mono-crop blooms of large scale industrial agriculture. Without this service, a large portion of contemporary agriculture would simply not be biologically or economically possible. ... In turn, modern industrial agriculture has been enabled by and transformed the honeybee: they work 2-4 more months than they use to, they are nomadic, they are treated by more chemicals for more dis-

138. Laura Reynolds and Danielle Nierenberg, "Disease and Drought Curb Meat Production and Consumption," in Vital Signs, vol. 20, ed. Worldwatch Institute (Washington, DC: Island Press, 2014), 49-52, quote at 51; see, e.g., Mike Davis, The Monster at Our Door: The Global Threat of Avian Flu (London: Verso, 2005).

139. Rowan Jacobsen, Fruitless Fall: The Collapse of the Honey Bee and the Coming Agricultural Crisis (New York: Bloomsbury, 2010). 
eases and given large quantities of supplemental high fructose corn syrup and cheap soy protein to boost their pollen production. ${ }^{140}$

Today, industrialized honeybee production is approaching a tipping point. Bee colony loss rates increased from an average of 10-15 percent in the second half of the twentieth century to 20-30 percent (often on the high end) since $2006 .{ }^{141}$ This is no small matter. given that we rely, directly and indirectly, on animal (especially bee) pollination for one-third of the food we eat. ${ }^{142}$ Some $\$ 19$ billion in American, and $\$ 200$ billion in world, agricultural output depends on this pollination. ${ }^{143}$ Although pollination costs are a small part of farm costs, the trend is not encouraging: hive costs have tripled-and labor productivity falteredover the past decade. ${ }^{144}$ Nor is the recent experience of southwest China encouraging-where hand-pollination is common and "where wild bees have been eradicated by excessive pesticide use and habitat" removal. ${ }^{145}$

Among the culprits is the deployment of neonicotinoid insecticides, introduced in the mid-1990s. And while the evidence indicting neonicotinoids for colony-collapse disorder is mounting, ${ }^{146}$ it seems clear that the problem is ani-

140. Jake Kosek, "The Natures of the Beast: On the New Uses of the Honey Bee," in Global Political Ecology, ed. Richard Peet, Paul Robbins, and Michael Watts (New York: Routledge, 2011), 245.

141. The White House, "Fact Sheet: The Economic Challenge Posed by Declining Pollinator Populations," 2014, accessed July 14, 2014, http://www.whitehouse.gov/the-press-office/2014/06/20/fact -sheet-economic-challenge-posed-declining-pollinator-populations; Brad Plumer, "Good News: Honeybee Deaths Went Down Last Winter," Vox, May 15 (2014), accessed July 13, 2014, http://www.vox.com /2014/5/15/5720232/good-news-honeybee-deaths-are-finally-declining; Josephine Marcotty, "Nature's Dying Migrant Worker," Star-Tribune, July 6, 2014, accessed July 14, 2014, http://www.startribune.com /local/264929101.html; Tennille Tracy, "More Beekeepers Sour on Profession as Winter Die-Offs Continue," Wall Street Journal, January 23, 2015, accessed January 24, 2015,http://www.wsj.com/articles /more-beekeepers-sour-on-profession-as-winter-die-offs-continue-1422057396.

142. Carol A. Kearns, David W. Inouye, and Nickolas M. Waser, "Endangered Mutualisms: The Conservation of Plant-Pollinator Interactions," Annual Review of Ecology and Systematics 29 (1998): 83-1 12.

143. Anne Fairbrother, John Purdy, Troy Anderson, and Richard Fell, "Risks of Neonicotinoid Insecticides to Honeybees," Environmental Toxicology and Chemistry 33, no. 4 (2014): 719-31; Sasha Ingber, "As Honeybees Die Off, First Inventory of Wild Bees Is Under Way: Could Wild Bees Be the Key to Saving U.S. Crops?" National Geographic online, July 11, 2014, accessed July 14, 2014, http:// news.nationalgeographic.com/news/2014/07/140711-wild-bees-north-america-honeybees-science/.

144. Marcotty, "Nature's Dying Migrant Worker"; Tracy, "More Beekeepers Sour."

145. Dave Goulson, "Decline of Bees Forces China's Apple Farmers to Pollinate by Hand," China Dialogue, October 2, 2012, accessed July 18, 2014, https://www.chinadialogue.net/article/show/single len/5193.

146. Fairbrother et al., "Risks"; Vincent Doublet et al., "Bees under Stress: Sublethal Doses of a Neonicotinoid Pesticide and Pathogens Interact to Elevate Honey Bee Mortality across the Life Cycle," Environmental Microbiology, published electronically 2014, doi: 10.1111/1462-2920.12426; Richard J. Gill and Nigel E. Raine, "Chronic Impairment of Bumblebee Natural Foraging Behaviour Induced by Sublethal Pesticide Exposure," Functional Ecology 28, no. 6 (2014): 1459-71. 
mated by the logic of capitalist beekeeping over the past century, one immanent in the agricultural revolution model that is now faltering. In the heartland of the long Green Revolution, the American Midwest, some 45 percent of bee species have been wiped out ${ }^{147}$ - a story sadly replicated across the globe's toxic landscapes of cash-crop cultivation. ${ }^{148}$

For colony-collapse disorder, read canary in a coal mine.

\section{AFTER THE LONG GREEN REVOLUTION? TECHNOLOGICAL EXHAUSTION AND THE NEW ONTOLOGICAL CHALLENGE}

Is another agricultural revolution on the horizon today? The short answer? No.

The basic contradiction is this: capitalist agriculture demands more and more energy to produce more and more calories with less and less labor power. This model has worked by combining technological and organizational advances with the appropriation of cheap soil, water, energy, and even labor. Industrial agriculture appears to be "intensive" but is in fact extensive. Like the capitalist factory, the capitalist farm requires more and more nature to flow through an average hour of labor (socially necessary labor time). For this reason, agriculture and industry in the capitalist world-ecology demand frontiers of uncapitalized nature; every act of producing surplus value requires an even greater act of appropriating the unpaid work/energy of nature, humans included! This explains the centrality of the commodity frontier in the history of capitalism, and the precocity of agroindustrialization on such frontiers-from the sugar mill to McCormack's reapers. ${ }^{149}$ The end of cheap food is the predictable result of the end of the frontier. A few frontiers remain. There are spaces of uncapitalized nature in the world-for soy farming in Mato Grosso (Brazil), or palm oil plantations in Borneo. ${ }^{150}$ But these are too small to restore cheap food.

147. Laura A. Burkle, John C. Marlin, and Tiffany M. Knight "Plant-Pollinator Interactions over 120 Years: Loss of Species, Co-occurrence, and Function," Science 339, no. 6127 (2013): 1611-15.

148. Jacobsen, Fruitless Fall.

149. Jason W. Moore, "The Capitalocene, Part I: On the Nature and Origins of Our Ecological Crisis," Journal of Peasant Studies (forthcoming), and "Capitalocene, Part II."

150. Not coincidentally, Indonesia enjoys the dubious distinction of having the world's highest rateand greatest regional extent-of deforestation in the twenty-first century. Brazil is second; see Belinda Arunarwati Margono, Peter V. Potapov, Svetlana Turubanova, Fred Stolle, and Matthew C. Hansen, "Primary Forest Cover Loss in Indonesia over 2000-2012," Nature Climate Change 4, no. 8 (2014): 730-35. Moreover-enter negative value-once land clearance is figured into national greenhouse gas emissions, both Indonesia and Brazil rank in the top ten emitters: respectively sixth and seventh; see Johannes 
The thesis I wish to explore in this final section is the relationship between the breakdown of capitalism's technological model and the rise of a new ontological politics that challenges not just the terms of productivism but its very logic. For some readers, the notion of technological breakdown will sound counterintuitive, even absurd. Do we not live in a world of unprecedented technological advance? In some ways, yes. Information flows faster, and to a greater number of people, than ever before. But for forty years, labor productivity growth has moved slowly, incrementally. High tech did not change that. The robot factories did not come. A long stagnation now lies ahead. ${ }^{151}$ Even this would not be such an immediate problem were it not for the rise of negative value, which threatens to turn slow growth into contraction. The genius of capitalism, through its manifold Cheap Nature strategies, was to outrun the rising costs of production by locating, creating, mapping, and quantifying natures external to capitalism but within reach of its power. Today, there is nowhere to run. Capitalism's survival turns on doing more than shifting the rising costs of climate change, energy production, and agriculture onto the account books of other capitalists: it turns on reducing costs for capital as a whole.

Is this possible? I am skeptical (about capitalism's survival), which means I am optimistic (about ours).

Historically, epoch-making technologies combine two great tasks. First, they have appropriated new streams of unpaid work/energy from the rest of nature. Second, they deliver these new streams, cheaply, into the circuit of capital as a whole. ${ }^{152}$ Labor productivity can therefore increase without being throttled by rising raw material costs. These technologies are usually not reducible to a single machine or tool. They typically revolved around large commodity complexes: the shipbuilding-cartographic revolution of early modernity or the transport and productive complexes clustered around the steam and internal combustion engines. The steam engine is our classic example. Put to work pumping water out of the coal mines, it is a frontier technology par excellence. The steam engine's develop-

Friedrich and Thomas Damassa, "The History of Carbon Dioxide Emissions," World Resources Institute blog, May 21, 2014, accessed August 8, 2014, http://www.wri.org/blog/2014/05/history-carbon-dioxide -emissions.

151. Gordon, "Is US Economic Growth Over?"; Tyler Cowen, The Great Stagnation (New York: Penguin, 2011).

152. Although some capitalists always benefit more than others, the point is crucial for it is often unappreciated today: the fact that some capitalists can turn handsome profits from, say, food speculation-as in the case of Goldman Sachs in recent years (Kaufman, Bet the Farm)_rising food prices do not benefit capital as a whole (Moore, "Cheap Food"). 
ment depended on the cheap energy it made possible. In turn, it radically extended capital's reach into the bounty of nature. The origins of the steam engine have everything to do with capitalism's drive to appropriate the unpaid work/energy of coal, the product of millions of years of earth-system work, and transform it into capital. Marx speaks of the capitalist labor process as one of turning "blood into capital." 153 Is this not also the same for coal, for forests, for the soil and water of farming? And we can go still further. As Marx reminds us in his discussion of the working day, it is not just soil but also human nature that is "robbed" in the normal processes of capital accumulation. ${ }^{154}$ The exhaustion of the soil and the worker is immanent to the accumulation of capital. Consequently, the accumulation of capital—and its technological apparatus—can only fix its recurrent crises through the appropriation of new frontiers of uncapitalized nature. The last frontiers that remain are now smaller than ever before, while capital's need for cheap natures is greater than ever before.

We can see this clearly in the nonappearance of a new agricultural revolution. ${ }^{155}$ Nearly three decades after the first signs of agricultural stagnation revealed themselves, ${ }^{156}$ there is little to suggest a new agricultural revolution in the making. The "second" industrial agriculture born of petrofarming and hybridization has yet to yield a third. There is a "yield plateau" for world agriculture today that appears, with mounting evidence, to be cumulative and not cyclical; it does not appear that this yield plateau can be transcended within the capitalist agricultural model. Even the rosy estimates of the Food and Agricultural Organization anticipate a one-third decline in the rate of output growthfrom 1.5 to 1 percent annually-over the next decade. ${ }^{157}$

Agricultural biotechnology, as we know, has sought to extend that model. It has failed, at best providing short-run gains to farmers, who quickly see those gains disappear, leaving them increasingly heavy debt burdens and forced to use more herbicides and pesticides. ${ }^{158}$ Very high agricultural productivity may, how-

153. Karl Marx, Capital, vol. 1, trans. Ben Fowkes (New York: Vintage, 1977), 382.

154. Ibid., 376.

155. Moore, "End of the Road?," and "Cheap Food."

156. Martin Kenney and Frederick Buttel, "Biotechnology: Prospects and Dilemmas for Third World development," Development and Change 16, no. 1 (1985): 61-91.

157. Organization for Economic Cooperation and Development-Food and Agricultural Organization, Agricultural Outlook, 2014-2023 (Paris: OECD Publishing, 2014), 130.

158. Gurian-Sherman, Failure to Yield; Charles M. Benbrook, "Impacts of Genetically Engineered Crops on Pesticide Use in the United States: The First Thirteen Years," The Organic Center (November 2009), www.organic-center.org; Moore, "Cheap Food"; Ashok Kumbamu, "Grounding Global Seeds" (PhD diss., University of Alberta, 2010). 
ever, be possible with alternative farming practices premised on agroecology, permaculture, and other noncapitalist agronomies. The spectacular, if episodic, success of the System of Rice Intensification-capable of producing more than 20 tons of rice on a hectare of land-is highly suggestive of such an alternate path. ${ }^{159}$

CLASS POLITICS AND THE NEW ONTOLOGY OF FOOD, NATURE,

AND VALUE

Such an alternative path can, of course, only be followed through class strugglebut a class struggle understood as a struggle over the configuration of the oikeios, that thorny, limiting, and liberating relation of life making on planet Earth. This is class struggle as the relation of production and reproduction, of power and wealth in the web of life. ${ }^{160}$ In this respect, the barriers to a new agricultural revolution are not limited to biophysical natures as such; they are coproduced through the class struggle, which is itself coproduced through nature.

It is much easier to celebrate the class struggle than to analyze it. We can say with some confidence that food—not just land-has become a central site of the world class struggle in a way that is entirely unprecedented, and that was unthinkable even three decades ago. To be sure, the struggle over food is more than a class struggle, and many forms of food justice appear quite modest: calls for supporting organic agriculture, local farmer's markets, Transition Towns, and so forth. But if neoliberal subjectivities persist—sometimes subtly and at others rudely embracing individualizing and market-dynamics-we are witnessing an important shift since the mid-2000s. This is the movement, unevenly cultural and political, toward "food justice": the popular face of food sovereignty in the Global North. ${ }^{161}$ As neoliberalism's macabre redefinition of has food rolled out-

159. Norman Uphoff, "Agroecological Implications of the System of Rice Intensification (SRI) in Madagascar," Environment, Development and Sustainability 1, nos. 3-4 (1999): 297-313; John Vidal, "India's Rice Revolution," The Guardian, February 16, 2013, accessed May 28, 2014, http://www.theguardian .com/global-development/2013/feb/16/india-rice-farmers-revolution, and "Miracle Grow: Indian Rice Farmer Uses Controversial Method for Record Crop," The Guardian, May 12, 2014, accessed May 28, 2014, http://www.theguardian.com/global-development/2014/may/13/miracle-grow-indian-rice-farmer -sri-system-rice-intensification-record-crop.

160. Jason W. Moore, "From Object to Oikeios: Environment-Making in the Capitalist WorldEcology" (unpublished manuscript, Fernand Braudel Center, Binghamton University 2013), and "Capitalocene, Part II"; Fraser, "Behind Marx's Hidden Abode."

161. See, inter alia, Alison Hope Alkon and Julian Agyeman, eds., Cultivating Food Justice: Race, Class, and Sustainability (Cambridge, MA: MIT Press, 2011); Alison Hope Alkon and Teresa Marie Mares, "Food Sovereignty in US Food Movements: Radical Visions and Neoliberal Constraints," Agriculture \& 
shifting from the Green Revolution's caloric metric to the "edible foodlike substances" that now line our supermarket shelves ${ }^{162}$-it seems to have made food, and by extension nature, much more fundamental to the Old Left questions of liberté, égalite, fraternité than ever before. The class struggle of the twenty-first century will turn, in no small measure, over how one answers the questions: What is food? What is nature? What is valuable?

Even on the basis of its strongest historical justification-the forces of production-capitalism now stumbles. For the alternative suggested by the System of Rice Intensification-taken in both literal and metaphorical senses of the concept-cannot be generalized except through a new imagining of food, nature, and value. It is in this sense that the agroecological alternative is a path that leads, necessarily, out of capitalism and toward a socialist world-ecology. ${ }^{163}$ This alternative can only be realized-can only be organized in the present-through a class struggle that redefines what is valuable (and what is not) in the civilization we wish to build. ${ }^{164}$

\section{TOWARD A SOCIALIST WORLD-ECOLOGY?}

What would a socialist valuation of humans and the rest of nature look like? This can only be answered through practical activity and reflexive theorization. But provisional answers, taken as guiding threads, ${ }^{165}$ can be offered.

In my view, the elements of a socialist world-ecology are all around us. And though these elements are not limited to food, food politics today offers some of the most hopeful glimpses of the future many of us wish to see. In the United States,

organic, urban, community-assisted and guerrilla agriculture are still small parts of the picture, but effective ones-a revolt against what transnational corporate food and capitalism generally produce. This revolt is taking place in the vast open space of Detroit, in the inner-city farms of West Oakland,

Human Values 28, no. 3 (2012): 347-59; Harriet Friedmann, "Food Sovereignty in the Golden Horseshoe Region of Ontario," in Food Sovereignty in Canada: Creating Just and Sustainable Food Systems, ed. Hannah Wittman, A. A. Desmarais, and N. Wiebe (Halifax: Fernwood, 2011), 168-89.

162. Michael Pollan, In Defense of Food: An Eater's Manifesto (New York: Penguin, 2008), 1.

163. Eric Holt-Giménez and Miguel A. Altieri, "Agroecology, Food Sovereignty, and the New Green Revolution," Agroecology and Sustainable Food Systems 37, no. 1 (2013): 90-102. One needn't, however, embrace Holt-Giménez and Altieri's smallholder populism to make such an argument.

164. McMichael, Food Regimes; Raj Patel, The Value of Nothing: How to Reshape Market Society and Redefine Democracy (New York: Picador, 2009).

165. Karl Marx, "Preface to A Contribution to the Critique of Political Economy," in The MarxEngels Reader, ed. Robert W. Tucker (New York: Norton, 1978), 4. 
in the victory gardens and public-housing of Alemany Farm in San Francisco, in Growing Power in Milwaukee and many other places around the country. These are blows against alienation, poor health, hunger and other woes fought with shovels and seeds, not guns. At its best, tending one's garden leads to tending one's community and policy, and ultimately becomes a way of entering the public sphere rather than withdrawing from it. $^{166}$

Even allowing for some measure of exaggeration in this statement-it is clear, for instance, that state power will be needed, in the United States and elsewhere, to reorient agriculture toward democratic and sustainable practices ${ }^{167}$ _food and agriculture has become a decisive battleground of the world class struggle. It is no longer largely a struggle of peasant against landlords. Food security, safety, and sustainability have become central questions in the everyday lives of the world proletariat, from Beijing to Boston. ${ }^{168}$

Such developments in the North are still modest in world perspective. In this respect, the rise of Vía Campesina signals an important development in the world history of food. ${ }^{169}$ Vía Campesina, representing some 200 million people, challenges the very heart of capitalist productivism in agriculture through its articulation of food sovereignty. Food sovereignty, at its best, asserts a revolutionary ontology of food-food as biospheric, as democratic, as cultural . . all at the same time. ${ }^{170}$ Each moment is implied in the others, "sustainability" unthinkable

166. Rebecca Solnit, "The Revolution Has Already Occurred," The Nation, June 27, 2008; see esp. the essays in Eric Holt-Giménez, ed., Food Movements Unite! (Oakland, CA: Food First Books, 2011), 115-221; and Alkon and Agyeman, Cultivating Food Justice.

167. And yet it is far from clear what such a deployment of state power would look like. The role of the state, as Bernstein rightly notes, is the "elephant in the room": not just in food sovereignty arguments but also red-green politics more broadly; see Henry Bernstein, "Food Sovereignty Via the 'Peasant Way': A Sceptical View," Journal of Peasant Studies 41, no. 6 (2014): 1031-63. See Friedmann's intriguing account of food politics that incorporates the role of the state in Toronto during the early 2000s (Harriet Friedmann, "Scaling Up: Bringing Public Institutions and Food Service Corporations into the Project for a Local, Sustainable Food System in Ontario," Agriculture and Human Values, 24, no. 3 (2007): 389-98; also Parenti, "Environment Making State."

168. Hon-Ming Lam, Justin Remais, Ming-Chiu Fung, Liqing Xu, and Samuel Sai-Ming Sun, "Food Supply and Food Safety Issues in China," The Lancet 381 (2013): 2044-53.

169. We must be careful to analyze closely Via Campesina's class divisions, which cannot be collapsed into a global peasantry; see Bernstein, "Food Sovereignty Via the 'Peasant Way,'" and Class Dynamics.

170. McMichael, Food Regimes; Hannah K. Wittman, Annette Aurélie Desmarais, and Nettie Wiebe, eds., Food Sovereignty: Reconnecting Food, Nature and Community (Halifax, NS: Fernwood, 2010); A. Haroon Akram-Lodhi, "How to Build Food Sovereignty," paper presented at the conference "Food Sovereignty: A Critical Dialogue," Yale University, September 14-15, 2013, accessed July 10, 2014, 
except through democratic and egalitarian praxis. In this vision, food sovereignty becomes the

right of peoples to healthy and culturally appropriate food produced through ecologically sound and sustainable methods, and their right to define their own food and agriculture systems. It puts the aspirations and needs of those who produce, distribute and consume food at the heart of food systems and policies rather than the demands of markets and corporations. It defends the interests and inclusion of the next generation. It offers a strategy to resist and dismantle the current corporate trade and food regime, and directions for food, farming, pastoral and fisheries systems determined by local producers and users. Food sovereignty prioritizes local and national economies and markets and empowers peasant and family farmer-driven agriculture, artisanal fishing, pastoralist-led grazing, and food production, distribution and consumption based on environmental, social and economic sustainability. Food sovereignty promotes transparent trade that guarantees just incomes to all peoples as well as the rights of consumers to control their food and nutrition. It ensures that the rights to use and manage lands, territories, waters, seeds, livestock and biodiversity are in the hands of those of us who produce food. Food sovereignty implies new social relations free of oppression and inequality between men and women, peoples, racial groups, social and economic classes and generations. ${ }^{171}$

But if class struggle is always present, it frequently takes "structural" forms. Capitalism's agricultural revolution model is about class; it is about capital; and it is about a capitalist project to make nature external, controllable, and cheap. Power, capital, and nature form an organic whole, not just in capitalist agriculture but for capitalism as a system—as a world-ecology. From this standpoint, the possibilities

http://www.tni.org/sites/www.tni.org/files/download/15_akramlodi_2013-1.pdf. Whether or not the historical agency of food sovereignty is represented by peasants (McMichael)—or "agrarian citizens" (Wittman)—is however is a different matter; see, respectively, Philip McMichael, "Peasant Prospects in the Neoliberal Age," New Political Economy 11, no. 3 (2006): 407-18; Hannah Wittman, "Reworking the Metabolic Rift: La Vía Campesina, Agrarian Citizenship, and Food Sovereignty," Journal of Peasant Studies 36, no. 4 (2009): 805-26. My sense is that semiproletarianization has proceeded to such a degree in agrarian zones worldwide that the usual characterization of peasantries no longer obtains. McMichael's political-ontological argument on food sovereignty is all the more compelling when situated with Bernstein's class-relational frame (Bernstein, Class Dynamics, and "Food Sovereignty Via the 'Peasant Way'"). Akram-Lodhi offers a perceptive argument along these lines in "How to Build Food Sovereignty."

171. La Vía Campesina, "Nyéléni Declaration on Food Sovereignty," Journal of Peasant Studies 36, no. 3 (2009): 673-76. 
for a new capitalist agricultural revolution are deeply constrained by the intensification of the practices and contradictions at the core of the long Green Revolution, now powerfully reinforced by climate change.

Capitalist agriculture today is headed toward-perhaps it is already in the midst of-an epochal transition. Where once capitalist agriculture contributed to capital accumulation by reducing the costs of labor power, it now threatens to increase those costs. In so doing, it undermines even the middle-run conditions for renewed capital accumulation. In this sense, we are living through the "last" food crisis: not because food insecurity will disappear, but because the food price spike that began in 2003-6 is an epochal, not developmental, turning point. This is signaled by the rise of negative value: socioecological shifts within the web of life that directly constitute barriers to endless accumulation. At the point of production, the superweed effect shows our future in the present: more energyand chemical-intensive strategies to discipline agroecologies as these evolve into forms of work/energy hostile to commodification. At the scale of the biosphere, the energy-intensive character of capitalist agriculture now feeds the spiral of global warming that increasingly limits capitalist agriculture itself.

Global warming poses a fundamental threat not only to humanity, but also, more immediately and more directly, to capitalism itself. This inverts the usual line of radical critique, which overstates the resilience of capitalism in the face of these changes - an overstatement that derives from a view of capitalism as a social system that acts upon nature, rather than a world-ecology that develops through the web of life. But the condition for maintaining negative value in its latent state was the possibility for moving entropy out of commodity production. Today, such latent negative value can no longer be moved out of commodity production. Planetary contradictions-from the biosphere (climate) to the body (disease)-are now penetrating global re/production relations with unusual power and salience. Global warming will, over the next two decades, so thoroughly mobilize heretofore latent negative value-fed by capitalist agriculture and in turn undermining the Cheap Food model-that it is difficult to see how the capitalist agricultural model can survive.

This is not only because of its internal contradictions (within the circuit of capital) but also because of the new ontological challenge to capitalism's valuation project itself (within capitalist civilization). Negative value is destabilizing surplus value, and in doing so it is making possible new, emancipatory and egalitarian vistas. Negative value, as it congeals from here forward, is a barrier to capital as such; its encouragement of a new ontological politics carries forth the possibility of alternative valuations of food, nature, and everything else. It is these alter- 
native valuations that will be absolutely critical in translating today's negative value into alternative ethico-political valuations that can become hegemonic. In revealing capitalism's value relations as the "value of nothing," ${ }^{172}$ the new contradictions and new movements bring into question the value of everything. The end of cheap food may well be the end of modernity, and the start of something much better. 